University of Nebraska - Lincoln

DigitalCommons@University of Nebraska - Lincoln

Agronomy \& Horticulture -- Faculty Publications

Agronomy and Horticulture Department

$5-2014$

\title{
Drivers of spatial and temporal variation in soybean yield and irrigation requirements in the western US Corn Belt
}

\author{
Patricio Grassini \\ University of Nebraska-Lincoln, pgrassini2@unl.edu \\ Jessica A. Torrion \\ Montana State University, jessica.torrion@montana.edu \\ Kenneth Cassman \\ University of Nebraska-Lincoln, kcassman1@unl.edu \\ Haishun Yang \\ University of Nebraska-Lincoln, hyang2@unl.edu \\ James Specht \\ University of Nebraska-Lincoln, jspecht1@unl.edu
}

Follow this and additional works at: https://digitalcommons.unl.edu/agronomyfacpub

Part of the Agricultural Science Commons, Agriculture Commons, Agronomy and Crop Sciences

Commons, and the Horticulture Commons

Grassini, Patricio; Torrion, Jessica A.; Cassman, Kenneth; Yang, Haishun; and Specht, James, "Drivers of spatial and temporal variation in soybean yield and irrigation requirements in the western US Corn Belt" (2014). Agronomy \& Horticulture -- Faculty Publications. 742.

https://digitalcommons.unl.edu/agronomyfacpub/742

This Article is brought to you for free and open access by the Agronomy and Horticulture Department at DigitalCommons@University of Nebraska - Lincoln. It has been accepted for inclusion in Agronomy \& Horticulture -Faculty Publications by an authorized administrator of DigitalCommons@University of Nebraska - Lincoln. 


\title{
Drivers of spatial and temporal variation in soybean yield and irrigation requirements in the western US Corn Belt
}

\author{
Patricio Grassini, ${ }^{1}$ Jessica A. Torrion, ${ }^{2}$ Kenneth G. Cassman, ${ }^{1}$ Haishun S. Yang, ${ }^{1}$ and James E. Specht ${ }^{1}$ \\ 1. University of Nebraska-Lincoln, P.O. Box 830915, Lincoln, NE 68583-0915, USA \\ 2. Montana State University, Northwestern Agricultural Research Center, 4570 MT Hwy 35, Kalispell MT 59901, USA \\ Corresponding author - P. Grassini, email pgrassini2@unl.edu \\ E-mail addresses: jessica.torrion@montana.edu (J.A. Torrion); kcassman1@unl.edu (K.G. Cassman); \\ hyang2@unl.edu (H.S. Yang); jspecht1@unl.edu (J.E. Specht)
}

\begin{abstract}
Both rainfed and irrigated soybean production are important in Nebraska (western US Corn Belt), accounting for a respective 48 and $52 \%$ of the state's soybean production of $7 \mathrm{Mt}$ on a respective 55 and $45 \%$ share of the state soybean area of 1.9 Mha. To date, no assessment of factors that may account for regional and inter-annual variation in yield and irrigation amount has been performed. To accomplish that objective, we evaluated a database containing on-farm field yields and total irrigation amount used in those fields. These data have been collected annually from $c a .1000$ soybean fields in six regions of Nebraska during the past eight years. Distributions of farm yield and irrigation amount were analyzed and the impact of selected weather variables and key management factors on these two variables was assessed. For irrigated soybean, attainable yields were estimated from the 95th percentile of the yield distribution, and yield gaps were then calculated as the difference between the attainable yield and average farm yield. The interquartile range for yield and irrigation amount was used as a measure of the management gap between skillfully and sub-optimally managed fields. Distribution of irrigated yield and irrigation amount were skewed, indicating that many producers achieved yields relatively close to the attainable yield, but also that irrigation in excess of the amount needed may have occurred in an important fraction of the total fields. Variation in rainfed yield was strongly related to July-August total rainfall and seasonal water deficit, but, in contrast, no single meteorological factor could consistently explain variation in irrigated yield. In fact, sowing date explained most of the observed inter-annual variation in irrigated yield in all regions. Amount of irrigation applied in each year depended on both rainfall and reference evapotranspiration. Efficiency in use of irrigation water versus rainfall to produce seed yield was remarkably similar. Across regions, attainable yield of irrigated soybean in NE averaged $4.7 \mathrm{Mg}^{-1}$, with the yield gap averaging about $16 \%$ of the attainable yield. Variation in yield and irrigation amount among fields was more important than variation among years and even regions. Further research is needed to identify the causes for this observed field-to-field variation in yield and irrigation amount within the same year and region.
\end{abstract}

Keywords: Soybean, Glycine max L., Yield, Irrigation, Yield gap, Water-use efficiency

\section{Introduction}

The USA produces $84 \mathrm{Mt}$ of soybean [(Glycine Max (L.) Merr.] annually, which accounts for about $35 \%$ of global soybean production (USDA-National Agricultural Statistics Service, 2013; FAOSTAT, 2007-2011). About $85 \%$ of the U.S. total is produced in the Corn Belt, where the dominant cropping sequence is the 2-year maize-soybean rotation. Nebraska (NE) ranks fifth among U.S. soybean-producing states with about $6.6 \mathrm{Mt}$ total annual production on a 1.9 Mha harvested with soybean. A unique feature of NE soybean production, compared with other states in the US Corn Belt, is that although only $45 \%$ of the state's hectarage is irrigated, it accounts for $52 \%$ of state's soybean production. An assured water supply not only enhances yield, but also reduces year-to- year variation, compared with rainfed yields that depend on both total rainfall amount and its distribution during the growing season (Grassini et al., 2014). In NE, 5-year irrigated and rainfed soybean yields average a respective 3.9 and $3.1 \mathrm{Mg} \mathrm{ha}^{-1}$ (USDA-NASS). There is, however, considerable spatial and temporal variation in both rainfed and irrigated soybean yields, which could be attributed to weather, soil, and management factors and their interactions. However, there has been no attempt to study the underpinning causes for observed differences in rainfed and irrigated soybean yields among regions and years in NE. 
NE has the largest share $(15 \%)$ of irrigated crop area in the United States, a total of 3.5 Mha, of which about $90 \%$ is cultivated with maize $(65 \%)$ and soybean (25\%) (USDA-NASS, 2008). Pivot and surface irrigation is used on a respective 80 and $20 \%$ of the NE irrigated land. Ground water is the primary water source, with a total of 92,500 active irrigation wells in operation (USDA-NASS, 2011). Because NE irrigated agriculture is not subject to drought-induced fluctuation in crop yields, it has attracted investment in livestock feeding operations, biofuel refineries, and of course, multiple irrigation equipment manufacturers. There is, however, a growing concern about the long-term sustainability of irrigated agriculture in NE due to concerns about groundwater depletion and water quality (Scanlon et al., 2012). Despite these concerns, there is limited published research assessing on-farm irrigation water use, efficiency of irrigation water to produce grain, and underpinning factors that explain differences among years, regions, and farms. Using producerreported data, Grassini et al. (2011b) showed that irrigated maize in $\mathrm{NE}$ achieves a relatively high water productivity, although $c a .50 \%$ of the fields were likely to be over-irrigated and about $30 \%$ of total irrigation water use could be saved by replacing surface irrigation system by central pivots and better irrigation scheduling. This particular study was limited, however, to maize crops grown in a relatively small region in south-central NE and the underlying causes for the observed differences in irrigation amount among regions and years were not investigated.

Yield potential is defined as the yield of a crop cultivar when grown with water and nutrients non-limiting and biotic stress effectively controlled (Evans, 1993; Van Ittersum and Rabbinge, 1997). When grown under optimal conditions, crop growth rate is determined only by solar radiation, temperature, atmospheric $\mathrm{CO}_{2}$ and genetic traits that govern length of growing period, light interception by the crop canopy, and its conversion to biomass. Average on-farm soybean yield in NE is well below maximum yields $>6 \mathrm{Mg} \mathrm{ha}^{-1}$ measured in experimental plots or contest-winning fields across the US Corn Belt, which might suggest a large gap between actual and potential yields (Specht et al., 1999). However, no explicit quantification of yield gap has been performed for soybean in the US Corn Belt or other regions of the world. In the case of crop systems where producer yields are already high, and in the case of irrigated crop systems with little or no seasonal water stress, there is relatively close agreement between yield potential estimates based on maximum yields achieved by producers that occupy the upper percentiles of the yield distribution for a specific region-year versus estimates based on well-validated crop simulation models with a strong biophysical foundation or measured yields under near-optimal management conditions (Lobell et al., 2009; Van Ittersum et al., 2013). Therefore, for high-yield crop systems, such as irrigated soybean in $\mathrm{NE}$, a meaningful estimate of attainable yields can be determined for each region-year based on the yields attained by the best producers, which can be used, in turn, to estimate the size of the gap between attainable and average producer yields.

Availability of high-quality data on farm yields, inputs, and management practices is required for identifying major sources of spatial and temporal variation in yield, quantification of yield gaps, and alleviation of yield-reducing factors and inefficiencies in the use of agricultural inputs such as irrigation water and nitrogen fertilizer (Van Ittersum et al., 2013). However, on-farm data are usually not available at a temporal and spatial degree of resolution required for a robust assessment of crop-system productivity and input use, even in developed countries with relatively high data availability such as USA. For example, publicly accessible, on-farm yield data in NE are limited to an annual county yield average for irrigated and rainfed crops (USDA-NASS, http://quickstats.nass.usda.gov/). Likewise, despite the continuous public and scientific debate about the use of the US Great Plains aquifer as a source of freshwater for irrigated agriculture, data on irrigation amount are limited to a statewide average value reported every 5 years by the Farm and Ranch Irrigation Survey (USDA-NASS, FRIS, http://www.nass.usda.gov/Surveys/ Guide_to_NASS_Surveys/Farm_and_Ranch_Irrigation/index.asp). A single yield and irrigation average value, per region, provides little information about how these two parameters vary amongst the population of farms within a region. That information is needed, however, to reliably discern the factors accounting for spatial and temporal variation in these two parameters as a means to identify ways to improve water use efficiency without decreasing yields or profit.

A number of studies have assessed the sources of on-farm yield variation in sunflower (Mercau et al., 2001; Grassini et al., 2009), wheat (French and Schultz, 1984; Lobell et al., 2002; Calviño and Sadras, 2002; Sadras et al., 2002), rice (Laborte et al., 2012), cassava (Fermont et al., 2009), banana (Wairegi et al., 2010), and maize systems (Calviño et al., 2003a; Tittonell et al., 2008; Grassini et al., 2011a; Grassini et al., 2011b). Villamil et al. (2012) investigated sources of field-to-field variation in rainfed soybean yields in Illinois (central US Corn Belt) using on-farm data but just from one growing season. Only the set of studies by Calviño and Sadras (1999) and Calviño et al., 2003b and Calviño et al., 2003c have assessed sources of inter-annual and spatial variation in soybean rainfed yields using on-farm data collected from a large number of years and farms in the Pampas of Argentina ( 34 to $37^{\circ} \mathrm{S}$ ). This study documented strong associations between soybean yields and sowing date, water availability during the period of pod and grain setting, soil depth, and phosphorous fertilization. No previous study has attempted, however, to investigate sources of variation in yield or irrigation amount and efficiency within a region where both rainfed and irrigated soybean crop fields are often located adjacent to each other, and where sharp gradients of weather and soils co-exist within a relatively small geographic region, as it is the case in NE.

To address the dearth of knowledge about the drivers of observed spatial and temporal variation in soybean yield and irrigation amount in NE, in this paper we analyzed a large database containing on-farm field data collected annually from approximately 1,000 soybean commercial fields in six regions in NE during eight years (2004-2011). The number of years and regions was judged to be a suitable sample of a wide range of weather conditions. At the same time, the time interval (2004-2011) is short enough to justify an assumption of constant technology and, hence, assume that inter-annual variation in average yield is mostly due to weather variability and its associated impact on some key management decisions such as sowing date. Specific objectives of this paper are to (i) provide a quantitative analysis of on-farm soybean yield and total irrigation amount in NE, (ii) identify underpinning weather and management factors that explain spatial and temporal variation in these two parameters, and (iii) estimate irrigation-water use efficiency and yield gaps of irrigated soybean.

\section{Materials and methods}

\subsection{Nebraska Natural Resources Districts data reporting system}

State law divides NE into 23 Natural Resources Districts (NRDs, http://www.nrdnet.org/), each serving as a local government entity with authority to establish regulations and incentives to protect and conserve natural resources within the district. Each NRD sets its own priorities and develops its own programs to best serve local needs. Crop producers with fields located in pre-designated reporting areas are required to provide field-specific agronomic information to the 
local NRD office, including crop species sown, yield, applied nitrogen fertilizer, and amount of irrigation water (if any) used. Field size typically ranges from 30 to 60 ha. Soybean yields are machine-harvested and expressed at $13 \%$ moisture content. The reporting area and number of reporting fields is consistent among years, but varied among NRDs. Information provided by producers can be sometimes verified with the attached grain elevator tickets or yield maps, but the latter documentation is not mandatory. For the present study, we used data from 2004 to 2011 crop growing seasons.

\subsection{Weather and soils in the NRD reporting regions}

Soybean production area is located in the central and east regions of NE (Figure 1). Within this production area, annual growing degree days (GDD, $T_{\text {base }}=10{ }^{\circ} \mathrm{C}$ ) and total precipitation decreases from a respective 2000 to $1500{ }^{\circ} \mathrm{Cd}$ and 800 to $500 \mathrm{~mm}$ along a $400-\mathrm{km}$ SE-NW transect. Producer-reported data were aggregated into six areas, which were delimited based on dominant climate, soil, and landscape attributes as well as on dominant water regimes (Figure 1 and Table 1). The six defined reporting regions portray well the range of agro-climatic regions where crops are grown in NE, as previously delineated by Zhou et al. (2003). Average soil available water holding capacity (AWHC) ranges from 304 to $111 \mathrm{~mm}$ across regions. High and less variable values of AWHC were notable for the soils found in the south-central and south-west regions I and IV (274$304 \mathrm{~mm}, \mathrm{CV}<15 \%$ ), while the lowest AWHC values were evident in the north-central region VI $(111 \mathrm{~mm}, \mathrm{CV}=24 \%)$. The other regions (II, III, and V) exhibited intermediate AWHC values, but also with high spatial variation $(197-220 \mathrm{~mm}, \mathrm{CV}=31-44 \%)$.

Soybean sowing in NE typically begins $12-15$ days after maize sowing has started and is concentrated in the first three weeks of May, depending upon site-year specific weather conditions in early spring. Seeding rates typically range from 35 to 45 seeds $\mathrm{m}^{-2}$ which is generally sufficient to ensure an optimal plant density for yield maximization. Only indeterminate cultivars are grown in NE, and these span a maturity group (MG) range from 2.4 (north-central region) to 3.6 (south-west region) following the spatial gradient in growing season length (Figure 1). ${ }^{1}$ Annual patterns of incident solar radiation, maximum $\left(T_{\max }\right)$ and minimum temperature $\left(T_{\min }\right)$, precipitation, and reference grass-based evapotranspiration $\left(\mathrm{ET}_{0}\right.$, Penman-Monteith-FAO 56) for three locations that exhibit contrasting weather conditions at the ends of the N-S and E-W transects are shown in Figure 2: Holdrege (south-central region I); Beatrice (south-eastern region IV), and O'Neill (north-central region VI). The climate is continental, with cold winters and hot summers. Peak solar radiation, temperature, and $\mathrm{ET}_{0}$ occurs in July, which is coincident with the early soybean reproductive stages (R1-R4), then decreases slightly in August when most of the seed filling phase (R5-R6) takes place. Rainfall distribution follows a monsoonal pattern, with the majority of annual precipitation occurring in the May to September growing season (61\% at Holdrege, $63 \%$ at Beatrice, and $64 \%$ at O'Neill). Early season water deficits are rarely encountered due to the high soil water content attained in most seasons before or shortly after sowing because of the relatively high rainfall and low $\mathrm{ET}_{0}$ during April and May. Therefore, the soybean irrigation season typically commences after July 1st, except for fields with sandy soils where irrigation may have to be initiated earlier. Intensity and probability of water stress during reproductive stages increases along the $\mathrm{E}$ to $\mathrm{W}$ transect. Annual water deficit, estimated as difference between total precipitation and $\mathrm{ET}_{0}$, is $-735 \mathrm{~mm}$ in Holdrege, $-557 \mathrm{~mm}$ in Beatrice, and $-599 \mathrm{~mm}$ in O'Neill, well above the annual water deficit amount associated with eastern locations in the US Corn Belt such as Ames, Iowa $(-133 \mathrm{~mm})$. Hence, successful production of soybean in NE depends on stored soil moisture that accumulates from snow melt and spring rains, plus irrigation if available.

\subsection{Comparison of NRD versus NASS yield data}

To evaluate the quality of the NRD-collected data, the NRD soybean seed yields for the six reporting regions were compared with yield data independently collected by USDA-NASS. Annual average irrigated and rainfed soybean yields reported by USDA-NASS (http://quickstats.nass.usda.gov/) were retrieved for the 2004-2010 crop season for the counties that overlap with the area of the six NRD reporting regions. Agreement between both sources of yield data was assessed by calculating the root mean square error (RMSE) and mean error (ME) as follows:

$$
\begin{aligned}
& \mathrm{RMSE}=\sqrt{\frac{\sum\left(Y_{\mathrm{NRD}}-Y_{\mathrm{NASS}}\right)^{2}}{n}} \\
& \mathrm{ME}=\frac{\sum\left(Y_{\mathrm{NRD}}-Y_{\mathrm{NASS}}\right)}{n}
\end{aligned}
$$

where $Y_{\mathrm{NRD}}$ and $Y_{\mathrm{NASS}}$ are the producer-reported NRD yield average and the USDA-NASS county yield average, respectively, and $n=$ number of pairs of NRD and USDA-NASS yield data. Linear regression analysis was performed to assess biases in the relationship between NRD versus NASS yields and $t$-tests and confidence intervals were used to detect statistically significant departures of the slope and intercept estimates from null hypothesized values of one and zero, respectively. Also, paired $t$-tests were conducted to detect significant differences between NRD versus NASS irrigated and rainfed yields.

\subsection{Descriptive analysis of actual yields and applied irrigation amount}

For each region $\times$ year $\times$ water regime combination, descriptive statistics were calculated to analyze distributions of soybean yields and total irrigation amount, including mean, median, 5th and 95th percentiles, interquartile range (IQR), coefficient of variation $(\mathrm{CV}$, in $\%$ ), skewness, and kurtosis (Supplementary Table 1). IQR was calculated as the difference between the values at the upper and lower quartiles (i.e., the 75 th and 25 th percentile, respectively). A CV (hereafter called an inter-annual CV) was calculated to quantify year-to year variation in annual average yield or irrigation amount. Another $\mathrm{CV}$ (hereafter termed an intra-annual CV) was calculated to assess field-to-field variation in individual field yield or irrigation amount for a given region-year case. Normality of yield and irrigation amount distributions was assessed with a Shapiro-Wilks test $(P<0.001)$. Distributions of producer yield and total irrigation amount are presented as box plots. In each box plot, the lower and upper box boundaries are the 25th and 75th percentiles, the line inside the box indicates the median, the whiskers (error bars) above and below the box indicate the 90th and 10th percentiles, and the dots above and below the whiskers indicate the 95th and 5 th percentiles.

Following the method described by Lobell et al. (2002), a twoway analysis of variance (ANOVA) was used to quantify the relative importance of temporal (year-to-year) versus spatial (region-toregion) variation in yield and irrigation amount. The analysis was performed separately for irrigated and rainfed soybean. The residual of the ANOVA was taken as a measure of the field-to-field variability. Sources of field-to-field variability can arise from soil type,

1. The numbers 2.5 to 3.6 correspond to MG 2 and 3, with the decimal point number denoting more specifically, within a given maturity group zonal latitude region of 2 or 3 , where a given cultivar is most likely to be best adapted. 


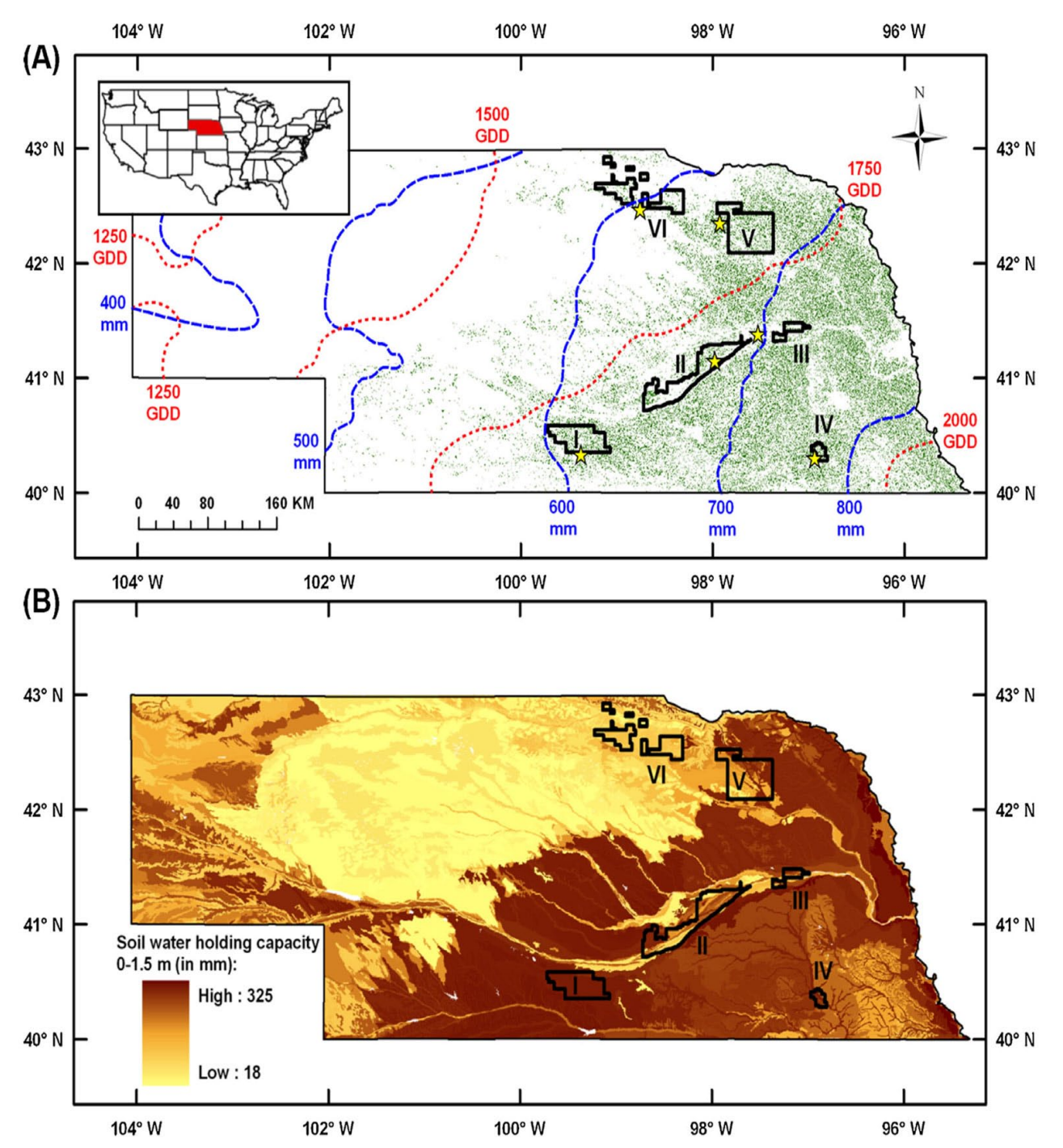

Figure 1. Map of the state of Nebraska showing the location of the six producer-data reporting regions (I to VI, black open polygons). Panel A: land planted with soybean is shown as green dots indicating density. Annual total rainfall isohyets (dashed blue lines) and total growing degree days isotherms (dotted red lines, $T_{\text {base }}=10^{\circ} \mathrm{C}$ ) are shown. Yellow stars indicate location of weather stations. Location of Nebraska within the contiguous United States is shown in the inset. Panel B: available soil water holding capacity $(0-1.5 \mathrm{~m}$, in $\mathrm{mm})$. Average annual total rainfall and soil available water holding capacity in the six regions are shown in Table 1. Sources of weather and soil data are the High Plains Regional Climate Center (HPRCC, www.hprcc.unl.edu) and STATSGO (Soil Survey Staff, USDANRCS, 2013), respectively.

farm management, or both, but were not analyzed in the present paper. The proportion of sums of squares attributable to year, region, year $\times$ region, and field-to-field variability was used to quantify the relative influence of each of these factors on yield and irrigation amount variation. The ANOVA was repeated 25 times using bootstrap resampling of 25 fields in each region-year each time to obtain a balanced experimental design because the number of reporting fields varied among regions (Table 1). The test indicated that using either a balanced versus unbalanced number of observations or different subsets of randomly selected fields has little impact on the results. Hence, in the present study, we report only the ANOVA results derived from using the entire database.

\subsection{Assessment of explanatory factors for variation on soybean seed yield and applied irrigation amount}

The influence of meteorological factors on soybean yields was assessed using Pearson correlation analysis. Yield and meteorological factors averages by region, year, and region-year were used to assess inter-annual, geospatial, and overall variability, respectively. Because weather impact on yields can be masked by management and soil factors, separate correlation analyses were performed using average seed yields and yields at the 95th yield percentile (hereafter called P95). Average daily incident solar radiation, $T_{\max }, T_{\min }$, relative humidity, total rainfall, photo-thermal quotient, number of days with $T_{\max }>34{ }^{\circ} \mathrm{C}$, sum of heat units above $34{ }^{\circ} \mathrm{C}$ on an hourly basis, total $\mathrm{ET}_{0}$, and total water deficit (rain minus $\mathrm{ET}_{0}$ ) were calculated for the period between July 1st and August 31st, which coincides roughly with the R1-R6 stages in soybean. Weather conditions for the July-August period are shown in Table 2 for each year over the 8-year (2004-2011) timespan. The correlation matrix showing the correlations among meteorological factors can be found in the Supplementary Table 1. Separate analysis using the July 15th-August 31st time interval (which covers roughly the R3-R6 stage period) showed no improvement in the predictive power of the meteorological factors; in fact, it decreased for rainfed crops (data not shown). Following Fischer (1985), a photo-thermal quotient $(Q)$ was calculated as the ratio between incident solar radiation and average temperature during the July 1st-August 31 st time interval. Briefly, $Q$ integrates the effects of solar radiation and temperature on crop growth and development during critical stages for yield determination. For the calculation of $Q$, a $T_{\text {base }}=0{ }^{\circ} \mathrm{C}$ was assumed for reproductive stages of soybean based on Setiyono et al. (2007). A threshold of $34{ }^{\circ} \mathrm{C}$ was chosen for stressful high temperature, based on data reported by Rondanini et al. (2003) and Cicchino et al. (2010) for sunflower and maize, respectively. Following Snyder (1985), the hourly sum of temperatures above $34{ }^{\circ} \mathrm{C}$ was performed using a sine function to interpolate between the $T_{\max }$ and $T_{\min }$ reported for each day. Pearson correlation coefficient $(r)$ and $F$-test $P$-values were calculated for all relationships. 
Figure 2. Monthly average incoming solar radiation, maximum $\left(T_{\max }\right)$ and minimum temperature $\left(T_{\min }\right)$, total rainfall, and total grass-based reference evapotranspiration based on long-term (1997-2012) weather data at stations located in Holdrege (southcentral, region I), Beatrice (south-eastern, region IV) and O'Neill (north-central, region VI). Error bars indicate \pm SE of the mean and are shown only for rainfall. Arrows in the bottom set of panels indicate average dates of soybean sowing, pod development (stages R3-R4) and physiological maturity (R7). Average ( \pm SE of the mean) annual water deficit (total rain minus $\mathrm{ET}_{0}$, in $\mathrm{mm}$ ) for the three stations is also shown in the bottom panels.
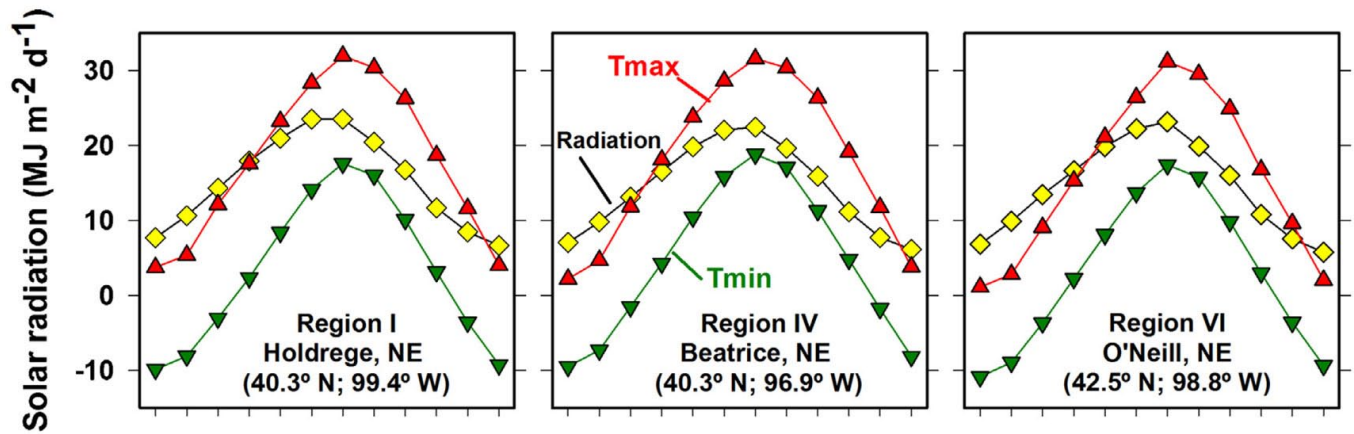

30

$20 \stackrel{3}{\frac{3}{x}}$ 10

$0 \stackrel{3}{3}$ อิ
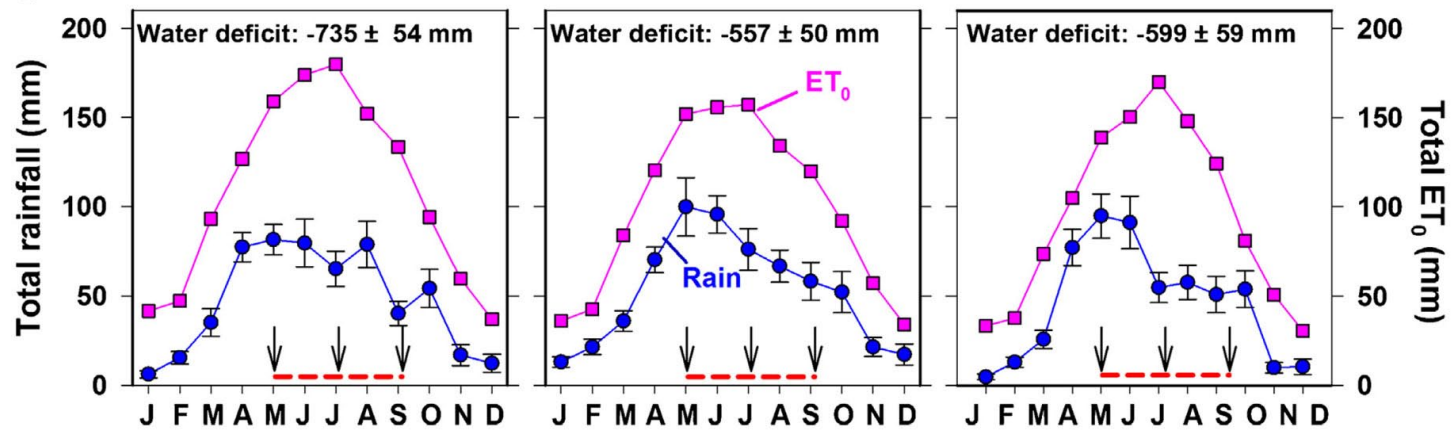

Table 1. Summary of some key characteristics of the six producer-data reporting regions.

\begin{tabular}{|c|c|c|c|c|c|c|c|}
\hline Region & Area & Water regimes ${ }^{\mathrm{a}}$ & $\begin{array}{l}\text { Average (2004 } \\
\text {-2011) reporting } \\
\text { fields per year }{ }^{\mathrm{b}}\end{array}$ & Topography & $\begin{array}{l}\text { Regional } \\
\text { weather } \\
\text { station }\end{array}$ & $\begin{array}{l}\text { Dominant soil series } \\
\text { (and average AWHC, } \\
0-1.5 \mathrm{~m})^{\mathrm{c}}\end{array}$ & $\begin{array}{l}\text { Total annual rain } \\
\text { and } \mathrm{ET}_{0}(\mathrm{~mm})^{\mathrm{d}}\end{array}$ \\
\hline I & South-central & $\begin{array}{l}\text { Irrigated } \\
\text { (P: 67\%, S: 33\%) }\end{array}$ & 157 & $\begin{array}{l}\text { Flat to gently } \\
\text { rolling } \\
\text { loess-covered }\end{array}$ & Holdrege & $\begin{array}{l}\text { Silt loam Holdrege } \\
(304 \mathrm{~mm} ; \mathrm{CV}=1 \%)\end{array}$ & $\begin{array}{l}\text { Rain: } 563 \pm 30 \\
\mathrm{ET}_{0}: 1298 \pm 26\end{array}$ \\
\hline II & $\begin{array}{l}\text { Central Platte } \\
\text { valley }\end{array}$ & $\begin{array}{l}\text { Irrigated } \\
(\mathrm{P}: 50 \%, \mathrm{~S}: 50 \%)\end{array}$ & 228 & $\begin{array}{l}\text { plains } \\
\text { Flat, wide alluvial } \\
\text { valley }\end{array}$ & Central City & $\begin{array}{l}\text { Holder silt loam, Lockton } \\
\text { loam \& Fonner loam }\end{array}$ & $\begin{array}{l}\text { Rain: } 582 \pm 41 \\
\mathrm{ET}_{0}: 1089 \pm 25\end{array}$ \\
\hline III & $\begin{array}{l}\text { East Platte } \\
\text { valley }\end{array}$ & $\begin{array}{l}\text { Irrigated \& rainfed } \\
(\mathrm{P}: 50 \%, \mathrm{~S}: 50 \%)\end{array}$ & $\begin{array}{l}72(\mathrm{I}) \\
25(\mathrm{R})\end{array}$ & $\begin{array}{l}\text { Flat, wide alluvial } \\
\text { valley }\end{array}$ & Monroe & $\begin{array}{l}(197 \mathrm{~mm} ; \mathrm{CV}=44) \\
\text { Holder silt loam, Lockton } \\
\text { loam\& Fonner loam }\end{array}$ & $\begin{array}{l}\text { Rain: } 562 \pm 39 \\
\mathrm{ET}_{0}: 1162 \pm 26\end{array}$ \\
\hline IV & South-east & $\begin{array}{l}\text { Irrigated } \\
(\mathrm{P}: 50 \%, \mathrm{~S}: 50 \%)\end{array}$ & 25 & $\begin{array}{l}\text { Flat to gently } \\
\text { rolling } \\
\text { loess-covered }\end{array}$ & Beatrice & $\begin{array}{l}(220 \mathrm{~mm}, \mathrm{CV}=31 \%) \\
\text { Crete silt loam \& } \\
\text { Wymore silty clay loam } \\
(276 \mathrm{~mm}, \mathrm{CV}=11 \%)\end{array}$ & $\begin{array}{l}\text { Rain: } 630 \pm 33 \\
\mathrm{ET}_{0}: 1186 \pm 26\end{array}$ \\
\hline VI & North-central & $\begin{array}{l}\text { Irrigated } \\
(\mathrm{P} \approx 100 \%)\end{array}$ & 142 & $\begin{array}{l}\text { Tablelands with } \\
\text { dissect slopes }\end{array}$ & O’Neill & $\begin{array}{l}\text { sand }(210 \mathrm{~mm}, \mathrm{CV}=37 \%) \\
\text { Jansen loam \& Dunday } \\
\text { loamy sand }(111 \mathrm{~mm} \text {, } \\
\mathrm{CV}=24 \%)\end{array}$ & $\begin{array}{l}\text { Rain: } 545 \pm 35 \\
\mathrm{ET}_{0}: 1144 \pm 30\end{array}$ \\
\hline
\end{tabular}

a. Percentage of pivot (P) and surface (S) irrigated fields is indicated. Groundwater is the major source of irrigation water, except for region II and III where surface water is also an important source.

b. Separate values are indicated for those regions for which reported data from irrigated (I) and rainfed (R) fields are available. 2004 data were not available in regions I and V.

c. Average available water holding capacity (AWHC) was calculated from STATSGO soil database (Soil Survey Staff, USDA-NRCS, 2013). The correspondingly regional median values were a respective $305,233,260,282,190$, and $112 \mathrm{~mm}$.

d. Long-term (1997-2012) averages ( \pm SE) for annual total rainfall and grass-based Penman-Monteith-FAO reference evapotranspiration (ET $)_{0}$ calculated following Allen et al. (1998) were based on the weather stations located within or near the data-reporting region. 
Sowing date is the management factor with the greatest impact on soybean yields in the US Corn Belt (Bastidas et al., 2008; De Bruin and Pedersen, 2008; Villamil et al., 2012; Rowntree et al., 2013). Linear regression analysis was used in the present study to assess the impact of sowing date on inter-annual yield variation in irrigated and rainfed soybean. For each region, annual average producer-reported seed yields were regressed against the date at which $50 \%$ of total area planted with area was achieved in each year. The date at which $50 \%$ sowing progress was achieved was calculated from the sowing progress data provided by the Risk Management Agency (RMA, http:// www.rma.usda.gov/) for each year from 2005 to 2011 for the counties where the NRD reporting regions are located. Separate estimates of date of $50 \%$ sowing progress were calculated for rainfed and irrigated soybean in each region-year. The RMA database coverage exceeded $80 \%$ of total soybean county harvested area reported by USDA-NASS, hence, the sowing date data used in the present study were highly representative of the entire population of soybean fields in each regionyear. Linear regression analysis was also used to investigate relationships between average total irrigation amount (dependent variable) and total rain, total $\mathrm{ET}_{0}$, and water deficit (independent variables) for each region. The three independent variables were computed for the time period of July 1st and August 15th, which coincides roughly with the irrigation season in NE. Slope, Pearson correlation coefficient $(r)$, and $F$-test $P$-value were calculated for all relationships.

Because distributions of yield and applied irrigation amount deviated from normality in a respective 61 and $52 \%$ of the cases (Shapiro-Wilks test, $P<0.001$ ), separate analyses were performed using the mean and median values. Using the median instead of the mean values improved correlations for applied irrigation, but not for yield (Table 3 and Table 5, Supplementary Tables 3 and 4). Hence, only the analysis results for average yield and median irrigation amount are shown.

\subsection{Yield gap and irrigation-water use efficiency of irrigated soybean}

We used P95 in each region-year as an estimate of the attainable irrigated yield for soybean and the yield gap was calculated as the difference between the attainable yield and the average irrigated yield. Attainable yield and yield gap were not calculated for rainfed soybean due to uncertainty in using P95 as a proxy to yield potential in water-limited cropping systems (Van Ittersum et al., 2013). Following Lobell et al. (2002), the magnitude of the IQR was used as a measure of the gap between skillfully-managed and sub-optimally managed fields, although the size of the IQR can also be determined by differences in soil type, irrigation system type, or both.

Following Howell (2001), irrigation water-use efficiency (IWUE) for each region-year was calculated as follows:

$$
\mathrm{IWUE}=\frac{Y_{\mathrm{IR}}-Y_{\mathrm{RF}}}{I}
$$

where $Y_{\mathrm{IR}}$ and $Y_{\mathrm{RF}}$ are the average producer irrigated and rainfed yield, respectively $\left(\mathrm{Mg} \mathrm{ha}^{-1}\right)$, and $I$ is the average producer-reported total irrigation amount $(\mathrm{mm})$. Separate estimates of IWUE were calculated for pivot- and surface-irrigated fields in region I, where reliable information on irrigation system type was available. County rainfed yield averages were retrieved from USDA-NASS for those regions for which rainfed $\mathrm{NRD}$-yield data were not available (i.e., regions I, II, IV, and V).

\subsection{Quantification of nitrogen supply}

Average annual $\mathrm{N}$ supply was calculated as the sum of soil $\mathrm{N}^{-\mathrm{NO}_{3}}{ }^{-}$at sowing, $\mathrm{N}$ fertilizer, and $\mathrm{N}^{-\mathrm{NO}_{3}}{ }^{-}$in applied irrigation in each region-year. $\mathrm{N}$ applied with manure was considered negligible because manure was applied in $<2 \%$ of the soybean fields. Soil $\mathrm{N}^{-\mathrm{NO}_{3}}{ }^{-}$at sowing comes from residual $\mathrm{N}$ of previous maize crop

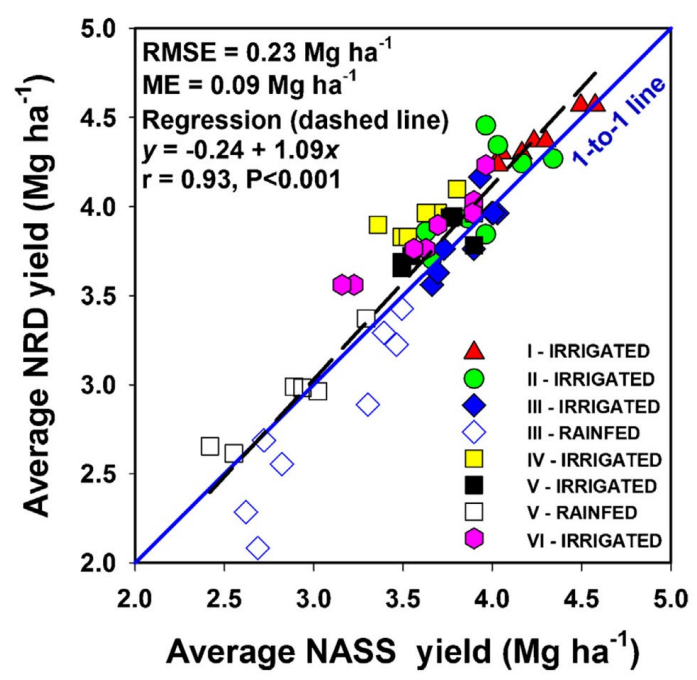

Figure 3. Comparison of the annual NRD reporting area mean soybean yields with the annual NASS yields for the counties located in those NRD areas. The data points indicate paired data for each of the six regions shown in Figure 1 for the 2004-2011 time period though 2004 data were not available for regions I and V. The regression and 1-to-1 lines are indicated by the respective dashed and solid lines.

and mineralization during the non-growing season and it was calculated based on $\mathrm{N}_{-} \mathrm{NO}_{3}{ }^{-}$measured in the upper 0-0.9 m layer before $\mathrm{N}$ application around sowing. Applied $\mathrm{N}$ fertilizer was calculated based on average $\mathrm{N}$ fertilizer rate and proportion of fields that received $\mathrm{N}$ fertilizer. Irrigation water $\mathrm{N}_{-} \mathrm{NO}_{3}{ }^{-}$was calculated based on total irrigation amount and measured $\mathrm{N}_{-} \mathrm{NO}_{3}{ }^{-}$in water samples collected from each well in each year. The relative contribution of each source of $\mathrm{N}$ to the total $\mathrm{N}$ supply was calculated.

\section{Results and discussion}

\subsection{Validation of NRD soybean seed yields against USDA-NASS county averages}

The producer-reported NRD yield data aligned well with yield data independently acquired and reported by USDA-NASS (Figure 3). Producer-reported NRD yields ranged from 2.1 to $4.6 \mathrm{Mg} \mathrm{ha}^{-1}$ across region-year cases. Average irrigated and rainfed yields were 4.0 and $2.9 \mathrm{Mg} \mathrm{ha}{ }^{-1}$, respectively. There was good agreement between producer-reported NRD and USDA-NASS county yield averages as reflected by the low RMSE $\left(0.2 \mathrm{Mg} \mathrm{ha}^{-1}\right)$ and $\mathrm{ME}\left(0.1 \mathrm{Mg} \mathrm{ha}^{-1}\right)$, which represent 6 and $2 \%$ of USDA-NASS yield average, respectively. There was no obvious bias in the comparison between NRD and USDANASS yields as indicated by the values of the slope (1.09) and intercept $(0.24)$ of the liner regression line, respectively, which were not significantly different from one $(P=0.17)$ and zero $(P=0.25)$, respectively. However, NRD irrigated and rainfed yields were slightly higher (ME: $0.1 \mathrm{Mg} \mathrm{ha}^{-1}$; paired $t$-test $P<0.001$ ) and slightly lower (ME: $-0.1 \mathrm{Mg} \mathrm{ha}^{-1}$; paired $t$-test $P=0.09$ ), respectively, than their corresponding USDA-NASS yields. The discrepancy in the rainfed subset of yield data was likely due to the producer-reported rainfed yield in region III, which over the eight years was consistently lower than USDA-NASS yield. Region III producer-reported rainfed soybean fields are located in a river valley of a single county, where sandy soils with low water holding capacity typically limit rainfed yields compared to rainfed yields in upland fields with heavier-textured soils elsewhere in the county. Thus, the USDA-NASS yields enumerated for random fields across the entire county are probably not the same population of fields in the producer-reported rainfed field dataset. In contrast, the cause of the small but consistent difference in irrigated yield between data sources is not clear. 


\subsection{Producer-reported yield and variation across regions and years}

Irrigation mitigates the yield limitation imposed by insufficient seasonal rainfall amount and/or inopportune timing of individual rainfall events, and the latter is critical with respect to the yield limitations that coarser soil textures impose on the available waterholding capacity. As a result, irrigated field yields tend to be higher and more stable than rainfed field yields (Figure 4). That said, the ANOVA results indicate there was still a significant effect of region, year, and region $\times$ year interaction on irrigated yields $(P<0.001)$ (Table 3), though the year effect was less than one-third that of the region effect (based on sum of squares for each factor). The nonsignificant region effect $(P=0.30)$ in the rainfed ANOVA likely reflects the fact that the only two regions with available rainfed yield data were adjacent to each other (regions III and V). As expected, the year effect (15\%) accounted for nearly all of the modeled effect $(18 \%)$. Average annual soybean irrigated yield ranged from 4.4 (region I) to $3.7 \mathrm{Mg} \mathrm{ha}^{-1}$ (region $\mathrm{V}$ ), with very small inter-annual CV (range: $3-6 \%$ across regions). Despite the significant year effect, there was no detectable linear trend in average annual irrigated yield $(P>0.15)$, although a time interval of eight years may be too short to detect a low-magnitude trend in these data, except for an increasing trend in rainfed soybean in region $\mathrm{V}(P=0.03)$, which was associated with a parallel increase in July-August rainfall in this region of about $14 \mathrm{~mm}$ per year from 2005 to $2011(P=0.05)$.

Without irrigation, soybean yields were substantively lower and more variable among years $\left(2.8 \mathrm{Mg} \mathrm{ha}^{-1}\right.$ in regions III and $\mathrm{V}$, with respective CV of 18 and 11\%). Remarkably, even in high-rainfall years (e.g., 2007, 2009, and 2010), the box plot distributions for rainfed yields were well below those for irrigated yields (Figure 4). The amount and timing of thunderstorm-mediated rainfall events tend to be (randomly) field specific and lengths of the rainfed yield box plots for any given year in Figure 4 are reflective of seasonal yield diversity in rainfed fields that accrues from that randomness. However, aside from the total seasonal crop water supply amount and its seasonal availability, one can hypothesize that non-water related factors also constrain productivity in rainfed fields. Notable in this regard are producer-mediated decisions. For example, it is likely that, over time, producers allocate their best fields on the farm to irrigated production. Also, producers tend to focus more time on management of crops in their irrigated fields to the detriment of crops in their rainfed fields, which is reflected in late sowing dates, the less common and lower N applications (see below Section 2.7), and lower P, K, and pesticides usage in rainfed fields (Grassini et al., 2014).

For most region-year datasets, the distribution of soybean irrigated yields was negatively skewed and exhibited positive kurtosis (Figure 4, Supplementary Table 2). Stated succinctly, producer-reported soybean field yields tended to have a well-defined distributional peak that was close to the maximum yields, with the skewing attributable to some low-yielding fields. Negatively skewed yield distributions have also been reported for other high-yield crop systems such as irrigated wheat grown in good soils in Yaqui Valley, northwestern Mexico (Lobell et al., 2002) and irrigated maize in south-central NE (Grassini et al., 2011a; Grassini et al., 2011b). However, this was not the case for rainfed soybean fields in regions III and V for which the yield distributions approached near-perfect normality. As it is evident in the box plots, intra-annual CVs for irrigated yield (15\%) were much larger than inter-annual CVs across regions (5\%) (Figure 2 and Supplementary Table 1). Greater intra- versus inter-annual yield variation in rainfed fields was also evident (22 versus $15 \%$, respectively). In fact, ANOVA indicated that, for both irrigated and rainfed crops, a relatively small portion of total observed yield variability was explained by region, year, and region $\times$ year interaction effects $(18 \%)$. The non-modeled residual variability in the error term (82\%) reflects field-to-field yield variation which may not be totally random but might, in fact, be partitioned into sources of variation just in addition to years and regions, as shown in Table 3, using field-specific data collected for crop management and soil type.

Inter-annual variation of soybean rainfed yields in regions III and $\mathrm{V}$ was strongly associated with total rainfall, and water deficit, and, to a lesser degree, $\mathrm{ET}_{0}$ during the reproductive phase (Figure 5, Table 4). These results are consistent with the strong relationship between soybean rainfed yield and water availability during the pod and grain setting periods reported by Calviño and Sadras (2002) in the southern Pampas (Argentina), indicating that water availability during key reproductive stages is the major driver of water-limited productivity. In contrast, there was no single meteorological factor that consistently explained variations in irrigated yields across years within the same region (temporal variation), across region within the same year (spatial variation), or both. Co-linearity among weather variables further complicated the interpretation of the linear regression analysis (Supplementary Table 1). For example, temporal variation in irrigated yield was not related with high temperatures $\left(>34^{\circ} \mathrm{C}\right)$ while a negative relationship was found for rainfed crops (Table 4). The latter was associated with increasing $\mathrm{ET}_{0}$ and water deficit as temperature increased (Table 4, Supplementary Table 1). In contrast, spatial yield variation was positively associated with high temperature $\left(T>34{ }^{\circ} \mathrm{C}\right)$ because the latter factor was, in turn, associated with warmer southern environments (region I), with earliest sowing dates, highest solar radiation, and relatively high $Q$, which, all together, resulted in higher average irrigated yield (Figure 4).

The impact of some meteorological variables on soybean yield can also be masked by crop management and soil texture type. When the correlation analysis for yield and meteorological factors was performed based on P95, the explanatory power of solar radiation and photo-thermal quotient in explaining the overall variation across all site-years increased compared with the analysis based on average yields (Supplementary Table 3). Likewise, when the analysis was based on P95, the impact of rainfall, $\mathrm{ET}_{0}$, and water deficit on rainfed yield became negligible in region II, probably because the P95 represents those fields with best soils or those that benefit the most from the erratic rainfall spatial distribution within the region in each year.

A single management factor, in this case sowing date, had a more consistent and stronger impact on irrigated yields than any weather factor (Figure 6). Yield decline associated with delayed sowing is associated with (i) shorter season length (V1-R7) leading to overall reduction in growth, (ii) lower number of reproductive nodes and grain number due to a shorter period from emergence to R5, and (iii) shorter seed filling period (Bastidas et al., 2008 and references cited therein). Depending upon the region and degree of delay in sowing, lower solar radiation and temperature during the reproductive phases in late- versus early sown crops can amplify the yield penalty. The yield penalty associated with one day of delay in sowing after May 1 st in the present study ranged from 10 to $41 \mathrm{~kg} \mathrm{ha}^{-1} \mathrm{~d}^{-1}$, which did not differ much from Bastidas et al. (2008) reported values of 17 and $43 \mathrm{~kg} \mathrm{ha}^{-1} \mathrm{~d}^{-1}$ for irrigated soybean grown in NE during two contrasting growing seasons. Similar yield declines with sowing delay (range: $18-63 \mathrm{~kg} \mathrm{ha}^{-1} \mathrm{~d}^{-1}$ ) have been reported for other sites in the central US Corn Belt by De Bruin and Pedersen (2008) and Villamil et al. (2012). Sowing date explained a significant portion of the variation in irrigated average yield and P95 across all site-years with respective responses of 29 and $25 \mathrm{~kg} \mathrm{ha}^{-1} \mathrm{~d}^{-1}(r=0.50$ and 0.45 , respectively; $P<0.005)$. Regressions based on relative yields, calculated as fraction of maximum yields or the yield achieved in the earliest sowing date, did not improve the goodness of fit (data not shown). The relationship between rainfed yield and sowing dates (regions III and $\mathrm{V})$ also exhibited a negative slope $\left(-28 \pm 22 \mathrm{~kg} \mathrm{ha}^{-1} \mathrm{~d}^{-1}\right.$, respectively) but it has lower explanatory power $(r=-0.33, P=0.20)$ compared with irrigated crops. Late sowing dates in 2007 and 2008 were associated, respectively, with the lowest average mean temperature 


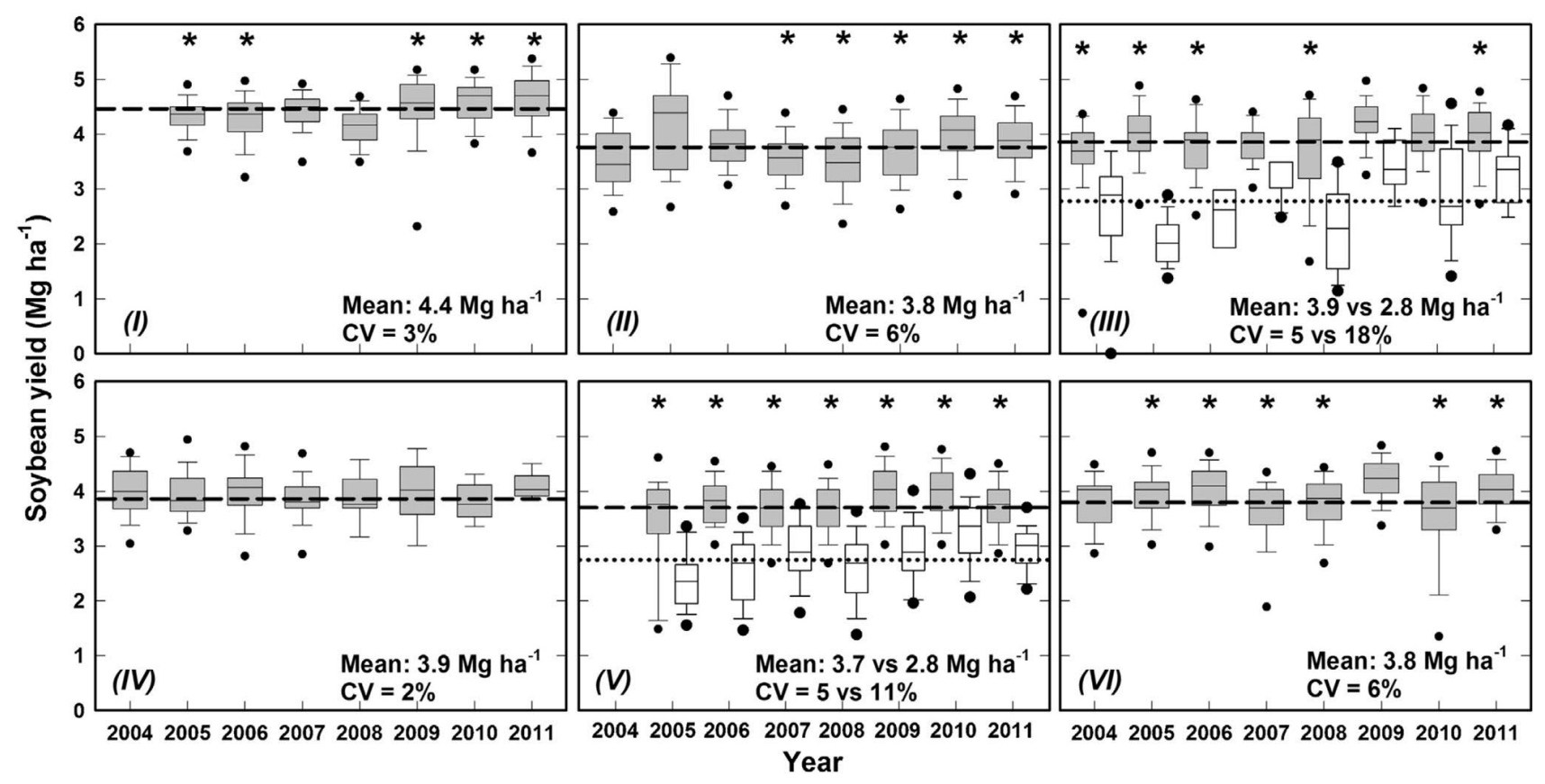

Figure 4. Box plots of annual producer-reported 2004 to 2011 soybean seed yields in irrigated fields located in each of the six regions (I to VI) (shaded boxes), though 2004 data were not available for region I and V. Lower and upper boundaries for each box are the 25th and 75th percentiles. The line inside each box indicates the median. Whiskers (error bars) above and below the box indicate the 90th and 10th percentiles. Dots above and below the whiskers indicate the 95th and 5th percentiles. Asterisks indicate that yield distribution deviates significantly from normality (Shapiro-Wilks test; $P<0.001$ ). Producer-reported data for rainfed soybean fields are also shown for region III and V (open boxes). The regional means over years and the inter-annual coefficient of variation (CV) are also presented.

$\left(10.9{ }^{\circ} \mathrm{C}\right)$ and highest total rainfall $(131 \mathrm{~mm})$ in the April 15-May 15 period among the $2005-2011$ crop seasons (7-year averages were $12.3^{\circ} \mathrm{C}$ and $82 \mathrm{~mm}$ ). In contrast, the early sowing date in 2009 was related to the lowest rainfall amount $(47 \mathrm{~mm})$ and the second highest average temperature $\left(12.6^{\circ} \mathrm{C}\right)$ during the April 15-May 15 time period. It is notable that the highest annual yield of $4.1 \mathrm{Mg} \mathrm{ha}^{-1}$ (average across regions) occurred in 2009 which, in turn, coincided with the earliest average sowing date and highest Q during the July-August time period $\left(1.0 \mathrm{MJ} \mathrm{m}^{-2} \mathrm{~d}^{-1}{ }^{\circ} \mathrm{C}^{-1}\right.$ ) (Table 1). Not surprisingly, lowest yields were achieved in 2007 and 2008 when sowing date was later than in other years. This was further aggravated in 2007 due to unfavorable weather conditions for crop growth during reproductive stages. Average July-August solar radiation and $T_{\min }$ in 2007 $\left(20.3 \mathrm{MJ} \mathrm{m}^{-2} \mathrm{~d}^{-1}\right.$ and $\left.18.1{ }^{\circ} \mathrm{C}\right)$ were the lowest and highest, respectively, among the eight years (2004-2011), resulting in the lowest $Q$ among years $\left(0.83 \mathrm{MJ} \mathrm{m}^{-2} \mathrm{~d}^{-1}{ }^{\circ} \mathrm{C}^{-1}\right)$ (Table 1). Finally, aside from the direct effect of sowing date on yield level, intra-annual yield variability also increased with later sowing date $(r=0.30, P=0.01)$.

The fact that the sign and explanatory power of the relationships between yield and meteorological factors varied depending on year, region, and water regime (rainfed versus irrigated crops), together with the significant co-linearity among meteorological factors (Supplementary Table 1) and influence of other managements factors (specifically sowing date), highlights the weaknesses of empirical, generic statistical models based on a weather parameters, selected without a strong biophysical justification, to estimate current and future yields on a local or global basis. As first proposed in the now classic papers authored in the mid-1980s by French and Schultz (1984) and Fischer (1985), and then further supported by Calviño and Sadras (1999), we argue in favor of simple, agronomically meaningful models based on few, key environmental and management factors as an alternative to large statistical models with numerous variables, which have limited biological relevance because of intrinsic empiricism and co-linearity among independent variables.

Table 2. Average $( \pm \mathrm{SE})$ daily solar radiation $(\mathrm{SR})$, maximum $\left(T_{\max }\right)$ and minimum temperature $\left(T_{\min }\right)$, respectively), photothermal quotient $(Q)$, number of days with $T_{\max }>34{ }^{\circ} \mathrm{C}(D>34)$, sum of hourly temperatures above $34{ }^{\circ} \mathrm{C}(T>34)$, relative humidity $(\mathrm{RH})$, total reference evapotranspiration $\left(\mathrm{ET}_{0}\right)$, rain, and water deficit (WD, total rain minus $\mathrm{ET}_{0}$ ) considering only the period between July 1 and August 31, which coincides with soybean reproductive stages (R1-R6). Values are averages across the six producer-data reporting regions.

\begin{tabular}{|c|c|c|c|c|c|c|c|c|c|c|}
\hline Year & $\mathrm{SR}\left(\mathrm{MJ} \mathrm{m}^{-2} \mathrm{~d}^{-1}\right)$ & $T_{\max }\left({ }^{\circ} \mathrm{C}\right)$ & $T_{\min }\left({ }^{\circ} \mathrm{C}\right)$ & $Q\left(\mathrm{MJ} \mathrm{m}^{-2} \mathrm{~d}^{-1}{ }^{\circ} \mathrm{C}^{-1}\right)$ & $D>34$ & $T>34\left({ }^{\circ} \mathrm{C} \mathrm{h}\right)$ & $\mathrm{RH}(\%)$ & $\mathrm{ET}_{0}(\mathrm{~mm})$ & Rain (mm) & $\mathrm{WD}(\mathrm{mm})$ \\
\hline $2004^{\mathrm{a}}$ & $20.2 \pm 0.6$ & $28.0 \pm 0.3$ & $15.1 \pm 0.3$ & $0.94 \pm 0.03$ & $6 \pm 1$ & $37 \pm 9$ & $74 \pm 2$ & $263 \pm 16$ & $145 \pm 22$ & $-188 \pm 36$ \\
\hline 2005 & $21.8 \pm 0.3$ & $30.5 \pm 0.3$ & $16.8 \pm 0.2$ & $0.92 \pm 0.01$ & $12 \pm 2$ & $117 \pm 44$ & $70 \pm 2$ & $315 \pm 11$ & $113 \pm 24$ & $-201 \pm 30$ \\
\hline 2006 & $21.4 \pm 0.5$ & $30.9 \pm 0.1$ & $17.3 \pm 0.3$ & $0.89 \pm 0.03$ & $15 \pm 1$ & $211 \pm 36$ & $70 \pm 2$ & $312 \pm 15$ & $144 \pm 21$ & $-168 \pm 31$ \\
\hline 2007 & $20.3 \pm 0.5$ & $30.7 \pm 0.3$ & $18.1 \pm 0.3$ & $0.83 \pm 0.02$ & $12 \pm 3$ & $73 \pm 27$ & $76 \pm 2$ & $279 \pm 12$ & $168 \pm 21$ & $-111 \pm 29$ \\
\hline 2008 & $21.3 \pm 0.2$ & $29.2 \pm 0.2$ & $16.1 \pm 0.2$ & $0.93 \pm 0.01$ & $5 \pm 1$ & $32 \pm 12$ & $74 \pm 1$ & $286 \pm 10$ & $133 \pm 19$ & $-153 \pm 28$ \\
\hline 2009 & $21.1 \pm 0.4$ & $27.8 \pm 0.2$ & $14.5 \pm 0.2$ & $1.00 \pm 0.02$ & $1 \pm 1$ & $5 \pm 3$ & $75 \pm 1$ & $267 \pm 7$ & $154 \pm 22$ & $-113 \pm 21$ \\
\hline 2010 & $21.9 \pm 0.4$ & $30.5 \pm 0.3$ & $17.6 \pm 0.3$ & $0.91 \pm 0.03$ & $7 \pm 2$ & $44 \pm 14$ & $75 \pm 1$ & $299 \pm 8$ & $154 \pm 16$ & $-144 \pm 13$ \\
\hline 2011 & $20.7 \pm 0.5$ & $30.6 \pm 0.3$ & $18.1 \pm 0.4$ & $0.85 \pm 0.03$ & $10 \pm 2$ & $94 \pm 34$ & $78 \pm 1$ & $271 \pm 12$ & $175 \pm 16$ & $-96 \pm 26$ \\
\hline 2004-2011 & $21.3 \pm 0.2$ & $30.6 \pm 0.4$ & $17.8 \pm 0.5$ & $0.88 \pm 0.02$ & $9 \pm 2$ & $77 \pm 23$ & $77 \pm 1$ & $286 \pm 7$ & $165 \pm 7$ & $-138 \pm 12$ \\
\hline
\end{tabular}

a. Regions I and V were not included in the year 2004 summary because producer-reported data were not available for these two regions. 

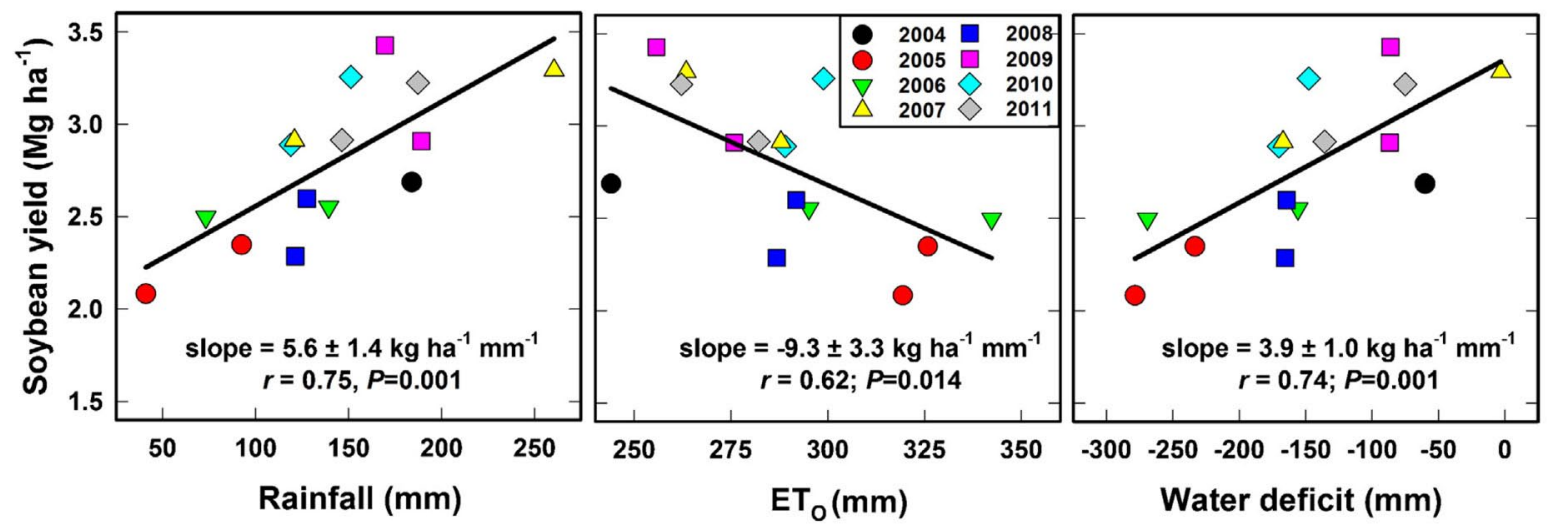

Figure 5. Relationship between rainfed soybean yields and July-August totals for the variables rainfall (left panel), reference evapotranspiration (ET ${ }_{0}$, central panel), and water deficit (right panel) in regions III and V during the 2004-2011 crop seasons. Each data point corresponds to a region-year case. Yield data were not available for region $\mathrm{V}$ in 2004. Linear regression slope $( \pm \mathrm{SE})$, Pearson correlation coefficient $(r)$, and $F$-test $P$-value are shown.
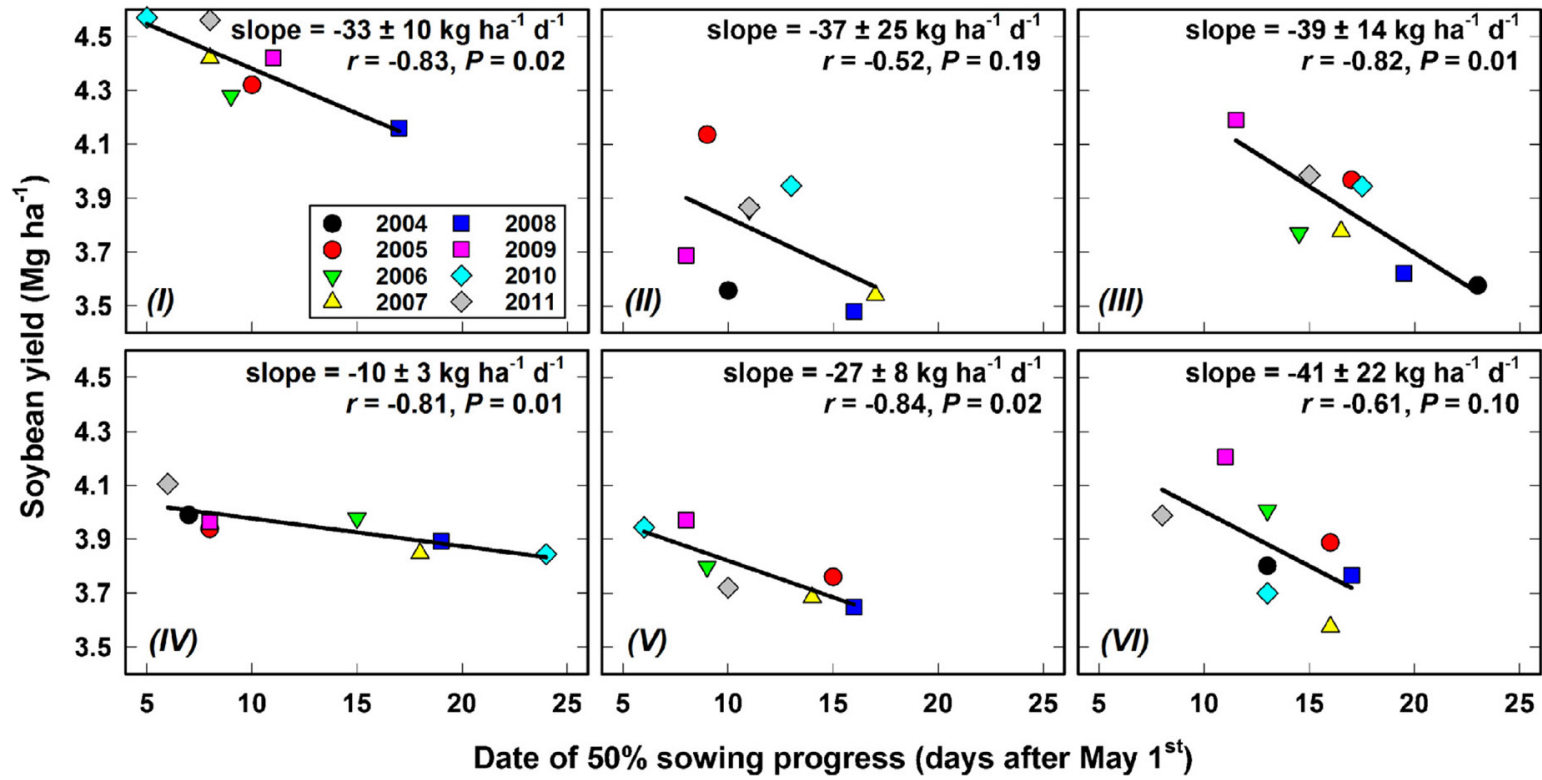

Figure 6. Relationship between annual irrigated soybean yield and the annual date at which $50 \%$ sowing progress was achieved in each data-reporting region during the 2004-2011 crop seasons. Each point corresponds to a region-year case. Yield data were not available for regions I and V in 2004. Linear regression slope ( $\pm \mathrm{SE})$, Person correlation coefficient $(r)$, and $F$-test $P$-value are shown.

Table 3. Analysis of variance (ANOVA) results for irrigated and rainfed soybean yields and irrigation amount.

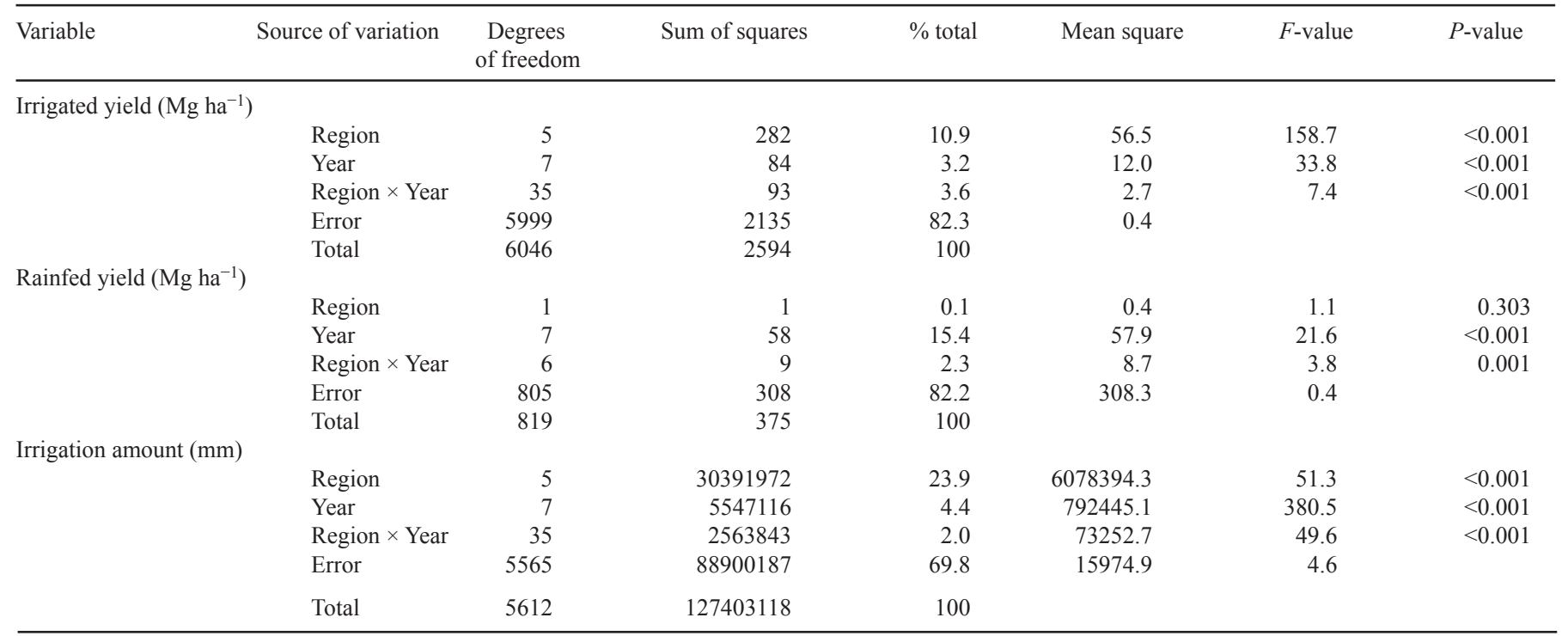




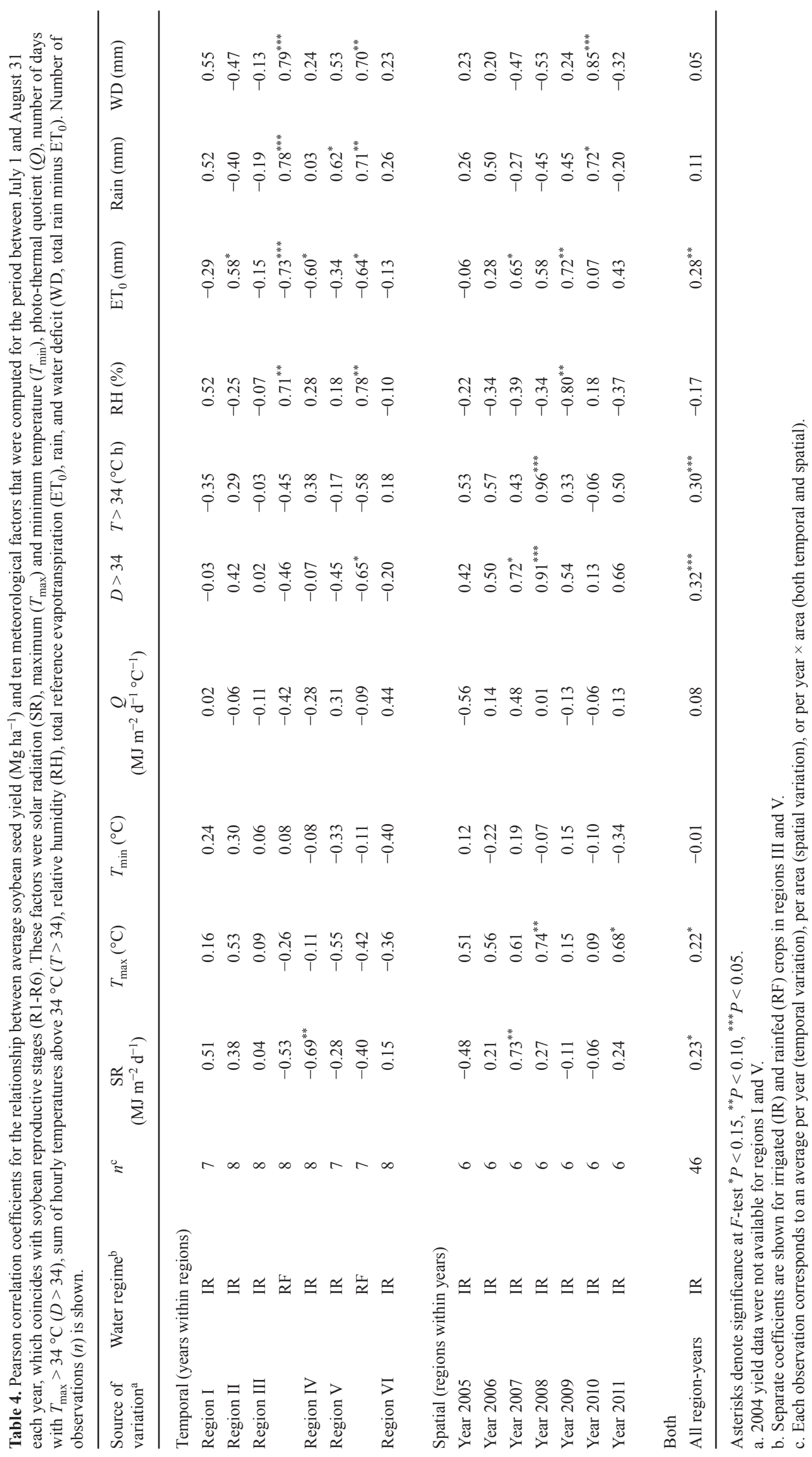



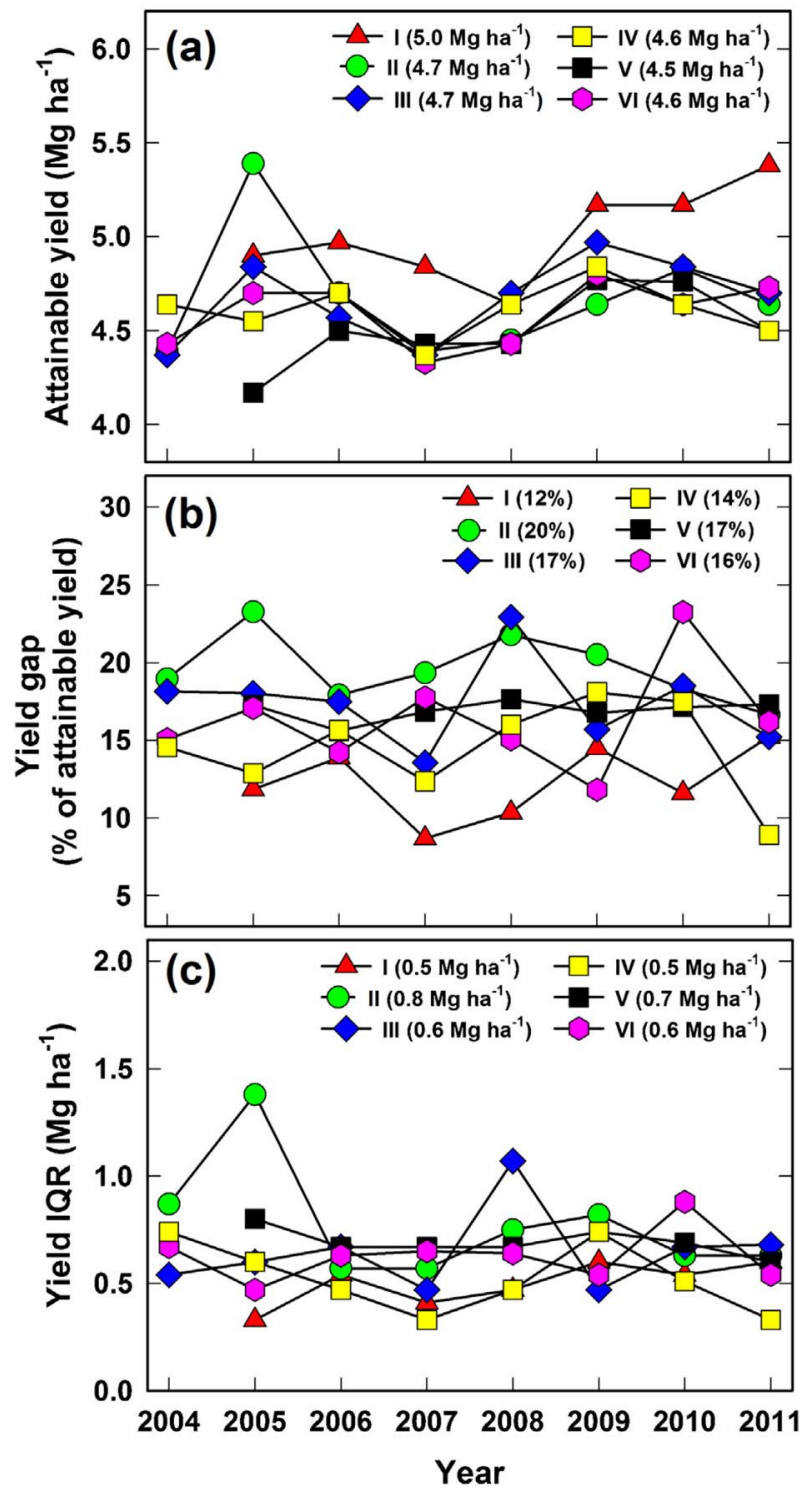

Figure 7. Trends over the 8-year timespan of NRD-based soybean data for (a) attainable yield, (b) yield gap (expressed as \% of attainable yield), and (c) yield interquartile range (IQR) for the six reporting regions from 2004 to 2011. Values were not calculated for regions I and V in 2004 because yield data were not available. Average values are indicated in the symbol legends in the three graphs. When averaged over regions, the yield potential, gap, and IQR was $4.7 \mathrm{Mg} \mathrm{ha}^{-1}, 16 \%$, and $0.6 \mathrm{Mg} \mathrm{ha}^{-1}$, respectively.

\subsection{Attainable yield and yield gaps in irrigated soybean production}

Attainable yield of irrigated soybean, derived from the P95 in each region-year, ranged from 4.2 to $5.4 \mathrm{Mg} \mathrm{ha}^{-1}$ with an overall average of $4.7 \mathrm{Mg} \mathrm{ha}^{-1}$ (Figure $7 \mathrm{a}$ ). Highest and lowest average attainable yields corresponded to regions $\mathrm{I}$ and $\mathrm{V}$, with a respective 5.0 and $4.5 \mathrm{Mg} \mathrm{ha}^{-1}$, and 2009 and 2007 crop seasons, with a respective 4.9 and $4.5 \mathrm{Mg} \mathrm{ha}^{-1}$. Variation in mean attainable yield across region-years was positively associated with radiation and Q during July and August (Supplementary Table 3) and negatively associated with sowing date $(r=0.50, P<0.001)$. The region-year values of attainable yield derived in the present study (range: 4.2 to $5.4 \mathrm{Mg} \mathrm{ha}^{-1}$ ) were below the attainable yield of $6.4 \mathrm{Mg} \mathrm{ha}^{-1}$ value estimated by Specht et al. (1999) to be a 'functional' yield benchmark for a large population of U.S. soybean producers. Onfarm yields $c a$. $6 \mathrm{Mg} \mathrm{ha}^{-1}$ might be achieved but only under the best possible genotype $\times$ location $\times$ year $\times$ management interaction across a large geographic area as reflected by the fact that, across the 6,867 reported soybean fields used in this study, the maximum individual-field yield reported was $5.8 \mathrm{Mg} \mathrm{ha}^{-1}$, which corresponds to an irrigated field in region I in 2010.

Average yield gap, expressed as percentage of the attainable yield, ranged from 9 to $23 \%$ across region-years, with an overall average of $16 \%$ (Figure $7 \mathrm{~b}$ ). Average yield gap of irrigated soybean in $\mathrm{NE}$ is amongst the smallest yield gap values reported in the literature for cropping systems (Lobell et al., 2009; Van Ittersum et al., 2013). The smallest and largest yield gaps were those in regions I (12\%) and II $(20 \%)$. The soybean yield gap value of $12 \%$ found in region I is very consistent with the reported yield gap of $11 \%$ reported by Grassini et al., 2011a and Grassini et al., 2011b for irrigated maize in the same region. The near-identical yield gap percentages for soybean and maize is remarkable, given the difference in the methodology used to compute yield potential (i.e., statistical analysis in the present study versus crop simulation modeling in Grassini et al., 2011a and Grassini et al., 2011b). Such a concurrence indicates that statistical approaches can be as effective as crop simulation models in providing robust estimates of yield potential in crop production systems with adequate water supply amount, good management, and high quality soils (Van Ittersum et al., 2013).

The IQR ranged from 0.3 to $1.4 \mathrm{Mg} \mathrm{ha}^{-1}$ across region-years, with an overall average value of $0.6 \mathrm{Mg} \mathrm{ha}^{-1}$ (Figure 7c). This irrigated soybean value is about half of the IQR reported by Lobell et al. (2002) for irrigated wheat in Mexico of $1.6 \mathrm{Mg} \mathrm{ha}^{-1}$ and this soybean-wheat difference is consistent even when the comparison is based on IQR values expressed as $\%$ of the average yield level in each study (15 versus $26 \%$, respectively). While some of the yield-reducing factors explaining the gap between high- versus low-yielding fields can be mitigated relatively easy (e.g., late sowing, incidence of diseases), weather-related factors are not manageable (e.g., hail, waterlogging) and soilrelated factors may require knowledge-intensive or non-economically viable solutions. Soil heterogeneity might also explain a portion of the yield gap because producers tend to apply uniform irrigation management in their fields, leading to sub- and supra-optimal irrigation amounts and variation in yield. For example, region II exhibited highly heterogeneous soils and, in turn, had the largest IQR in yield $\left(0.8 \mathrm{Mg} \mathrm{ha}^{-1}\right)$ and irrigation amount $(194 \mathrm{~mm})$.

\subsection{Producer-reported total irrigation amount and variation across regions and years}

The ANOVA indicated a significant region, year, and region $\times$ year interaction effect on irrigation amount $(P<0.001)$ (Table 3). Average annual irrigation amount ranged from 155 (region IV) to $396 \mathrm{~mm}$ (region VI), with relatively large inter-annual CVs (range: 8 to $29 \%$ across regions) (Figure 8). Largest average irrigation amounts corresponded to regions that exhibited all or some of the following conditions: large water deficit (I, II, and VI), relatively high proportion of surface-irrigated fields (I and II), and low soil water holding capacity (region II and VI) (Table 1, Figure 1 and Figure 2). In all regions but one (region IV), median irrigation amount declined over time at a rate that ranged from 8 to $26 \mathrm{~mm}$ per year $(P<0.10)$. The latter was associated with a parallel increasing trend in July 1 -August 15 total rainfall and water deficit during the 2004-2011 time period $(P<0.05)$ (Table $5)$. Inter-annual variation in median applied irrigation was negatively associated with July 1-August 15 total rainfall and water deficit and positively related with $\mathrm{ET}_{0}$ in all regions (Table 2). Water deficit integrated the effect of both rainfall and $\mathrm{ET}_{0}$ and had greater explanatory power than either of these two variables alone. The response 


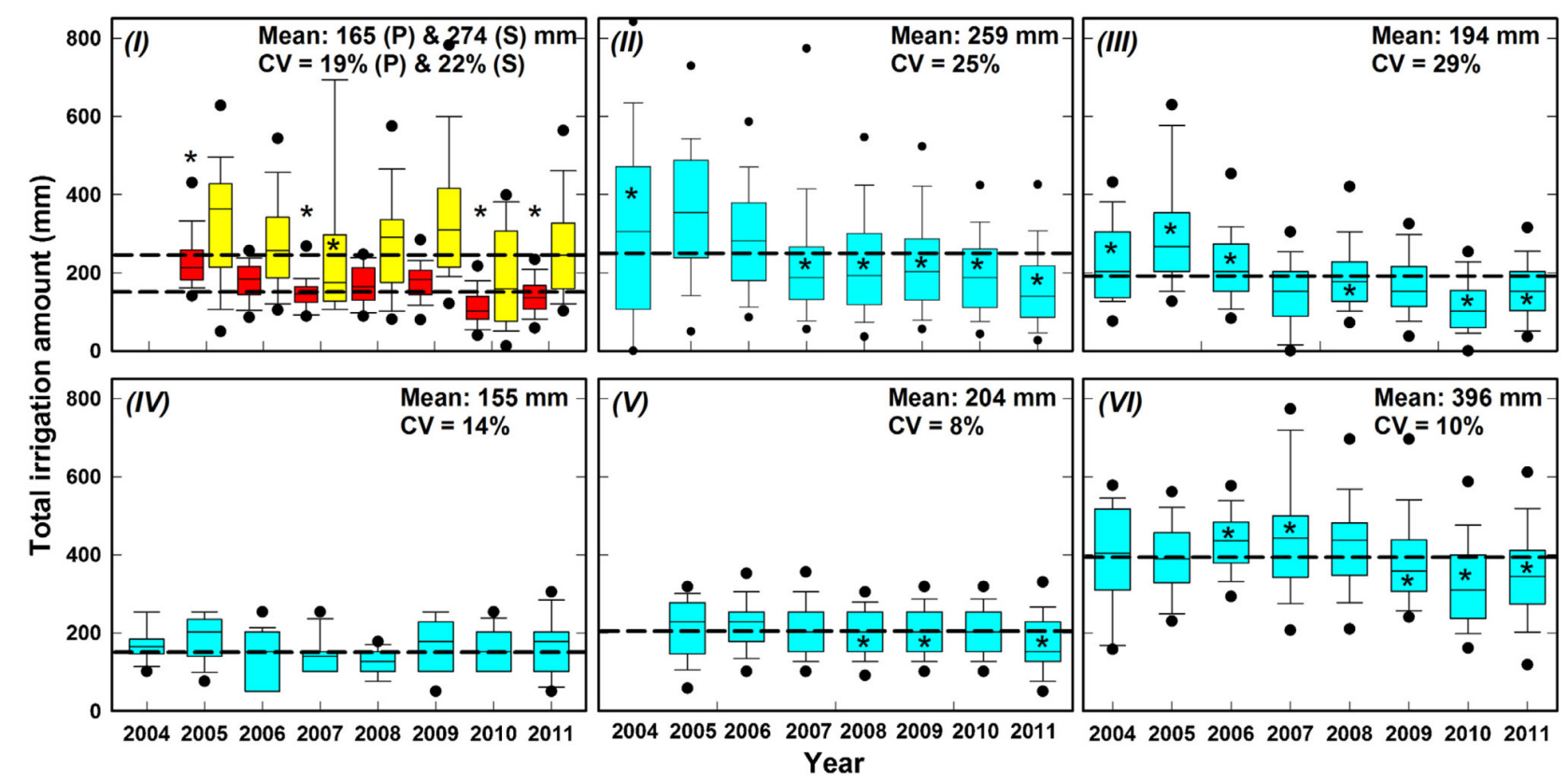

Figure 8. Box plots (blue shading) of annual producer-reported soybean total irrigation amount for each of the six regions from 2004 to 2011 , though 2004 data were not available for regions I and V. Producer-reported data were disaggregated into two irrigation system only in region I, with the pivot type denoted by red boxes and the surface type by yellow boxes. Lower and upper boundaries for each box are the 25 th and 75 th percentiles. The line inside each box indicates the median. Whiskers (error bars) above and below the box indicate the 90th and 10th percentiles. Dots above and below the whiskers indicate the 95th and 5th percentiles. Asterisks indicate that irrigation amount distribution deviates significantly from normality (Shapiro-Wilks test; $P<0.001$ ). In regions II, III, and IV, fields were surface- and pivot-irrigated in an approximate 50:50 ratio, while in regions IV, V, and VI nearly all fields were pivot irrigated. The regional means over years and the inter-annual coefficient of variation $(\mathrm{CV})$ are also shown.

of irrigation amount to additional rainfall, $\mathrm{ET}_{0}$ or water deficit was greater and has greater explanatory power in the driest regions (I, II, and VI) than in the more humid eastern regions (III and V). In essence, as the water deficit became larger (i.e., more negative), producers in the driest regions applied relatively more irrigation compared with their counterparts in humid regions (ca. 0.6 versus $0.4 \mathrm{~mm}$ of irrigation $\mathrm{mm}^{-1}$ water deficit, respectively).

The distribution of total irrigation amount was positively skewed, with a well-defined peak as reflected by the positive kurtosis, indicating that there was an important number of fields that likely received excessive irrigation amount (Figure 8, Supplementary Table 1). Similar to yield, irrigation amount exhibited much higher intra-annual than inter-annual variation (average $\mathrm{CV}$ across regions was a respective 46 versus 18\%). In fact, the ANOVA results indicated that $70 \%$ of the variation in irrigation amount was attributable to field-to-field variation (Table 3). The IQR averaged $117 \mathrm{~mm}$, ranging from 64 (region I, pivot-irrigated fields) to $194 \mathrm{~mm}$ (region II) (Figure 9a). Interestingly, no consistent relationship between intra-annual variability in irrigation amount and either IQR, intra-annual $\mathrm{CV}$, rainfall, $\mathrm{ET}_{0}$, or water deficit was found in any of the regions, indicating that the causes for field-to-field variation in irrigation amount were persistent across years, except in extremely dry years such as 2004 in region II and III (Figure 9a). Field-to-field variation in irrigation amount can be associated with differences in irrigation systems (pivot, surface), irrigation scheduling, and soil texture among fields. Variation in irrigation amount was much lower in pivot- versus surface-irrigated fields for region I with respective CVs of 35 and 54\% (Figure 8 and Figure 9a). Higher variability among surface-irrigated fields is not surprising because an efficient surface-irrigation management requires a knowledge-based and labor intensive skill that ensures recharging the soil water content in the crop root zone, applying water uniformly along the furrows, and minimizing runoff, all of which is dependent on soil conditions, field topography, row spacing, length of furrows, and re-use of irrigation runoff (Yonts et al., 2007). Hence, an important portion of the variability in irrigation amount in regions I, II and III can be attributable to the relatively high proportion of surface-irrigated fields ( $\mathrm{ca} .50 \%$ of total irrigated fields). High soil variability within regions II, III and V may also be a factor explaining field-to-field variation in irrigation amount (Figure 1, Table 1). It is remarkable that, even in regions with relatively homogenous

Table 5. Linear regression analysis results for the variables of median total irrigation amount (dependent variable) relative to the independent variables of total July 1-August 15 rain, reference evapotranspiration $\left(\mathrm{ET}_{0}\right)$, and crop water deficit (calculated as rain minus $\left.\mathrm{ET}_{0}\right)$. Linear regression slope $(b \pm$ standard error), Pearson correlation coefficient $(r)$, and $F$-test $P$-value for the regression are shown for each region. Region IV data were omitted because the proportion of surface- and pivot-irrigated reporting fields was not consistent across years.

\begin{tabular}{|c|c|c|c|c|c|c|c|c|c|}
\hline Region $^{\mathrm{a}}$ & $\begin{array}{l}\text { Rain }(\mathrm{mm}) \\
b(\mathrm{~mm} \text { irrigation } \\
\left.\mathrm{mm}^{-1} \text { rain }\right)\end{array}$ & $r$ & $P$-value & $\begin{array}{l}\mathrm{ET}_{0}(\mathrm{~mm}) \\
b(\mathrm{~mm} \text { irrigation } \\
\left.\mathrm{mm}^{-1} \mathrm{ET}_{\mathrm{O}}\right)\end{array}$ & $r$ & $P$-value & $\begin{array}{l}\text { Water deficit }(\mathrm{mm}) \\
b(\mathrm{~mm} \text { irrigation } \\
\left.\mathrm{mm}^{-1} \text { water deficit }\right)\end{array}$ & $r$ & $P$-value \\
\hline I & $-0.82 \pm 0.43$ & -0.65 & 0.11 & $1.24 \pm 0.57$ & 0.70 & 0.08 & $-0.65 \pm 0.25$ & -0.79 & 0.07 \\
\hline III & $-0.44 \pm 0.32$ & -0.50 & 0.20 & $1.15 \pm 0.67^{b}$ & 0.57 & 0.14 & $-0.47 \pm 0.22^{b}$ & -0.54 & 0.15 \\
\hline V & $-0.51 \pm 0.26$ & -0.66 & 0.10 & $0.73 \pm 0.30$ & 0.73 & 0.06 & $-0.32 \pm 0.14$ & -0.71 & 0.07 \\
\hline VI & $-0.73 \pm 0.40$ & -0.60 & 0.12 & $0.93 \pm 0.69$ & 0.48 & 0.22 & $-0.54 \pm 0.27$ & -0.70 & 0.07 \\
\hline
\end{tabular}

a. Irrigation amount data were not available for regions I and V in 2004.

b. Quadratic regression was also significant $(F$-test $P<0.10)$ in this region. 


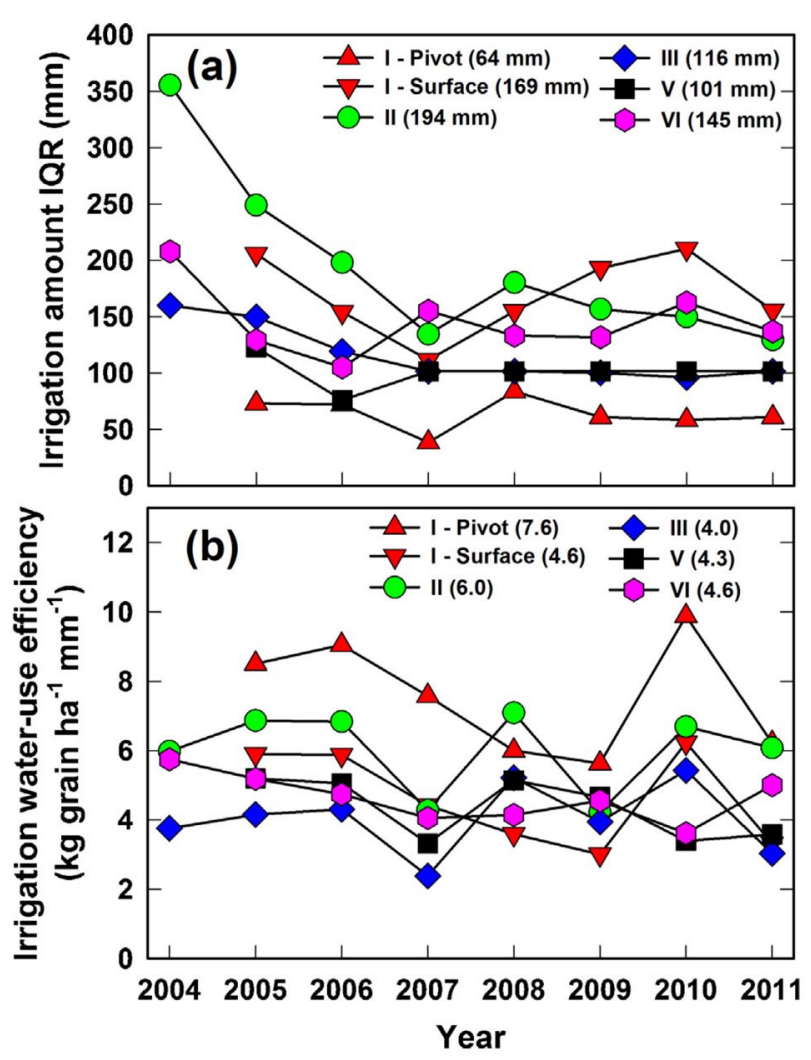

Figure 9. Trends over the 8-year timespan of NRD-based soybean data for (a) total irrigation amount in the interquartile range (IQR) of collected data and (b) irrigation-water use efficiency in each of the reporting regions from 2004 to 2011. The 2004 data for regions I and V were not available and region IV data were omitted because the proportion of surface- and pivot-irrigated reporting fields was not consistent across years. Average IQR and IWUE in each region are indicated in parenthesis in the symbol legends. Separate trends are shown for pivot- and surface-irrigated fields in region I. Average IWUE and IQR was $5.5 \mathrm{~kg} \mathrm{ha}^{-1} \mathrm{~mm}^{-1}$ and $117 \mathrm{~mm}$, respectively, across regions.

soils, and same type of irrigation system, a large variation in irrigation amount applied in the same year was still evident, as reflected by the large CV and IQR in regions I and VI in Figure 8 and Figure 9a. Despite the fact that reporting regions were relatively small, the spatial variability in rainfall might explain a portion of the field-to-field variation in irrigation amount. However, it is likely that differences in irrigation management, and particularly in irrigation scheduling account for a major portion of the observed field-to-field variation as found in previous studies in irrigated maize in NE (Grassini et al., 2011b; Irmak et al., 2011).

Average on-farm IWUE across region-years was $5.5 \mathrm{~kg} \mathrm{ha}^{-1} \mathrm{~mm}^{-1}$, ranging from 2.4 to $9.9 \mathrm{~kg} \mathrm{ha}^{-1} \mathrm{~mm}^{-1}$ (Figure $9 \mathrm{~b}$ ). Remarkably, efficiency in the use of irrigation versus rainfall water to produce seed yield was almost identical as can be inferred by comparison of the average on-farm IWUE of $5.5 \mathrm{~kg} \mathrm{ha}^{-1} \mathrm{~mm}^{-1}$ and the $5.6 \mathrm{~kg} \mathrm{ha}^{-1} \mathrm{~mm}^{-1}$ slope value of the relationship between soybean rainfed yield and total rainfall during the reproductive phase (Figure 3). Also, the range of on-farm IWUE compares well with previous reported values of water-use efficiency for soybean in NE. Using an experimental design that included 6 water treatments and 19 high-yield commercial soybean cultivars replicated in two growing seasons with contrasting water supply amount and distribution in eastern NE, Specht et al. (2001) found average IWUE values of 2.6 (wet season) and $4.7 \mathrm{~kg} \mathrm{ha}^{-1} \mathrm{~mm}^{-1}$ applied irrigation (dry season). In another study, Suyker and Verma (2009) estimated soybean water-use efficiency of $c a .8 \mathrm{~kg} \mathrm{ha}^{-1} \mathrm{~mm}^{-1}$ crop ET (yield adjusted to $13 \%$ moisture) based on eddy covariance flux measurements in commercial-scale rainfed and irrigated fields during two growing seasons. The $8 \mathrm{~kg} \mathrm{ha}^{-1} \mathrm{~mm}^{-1}$ value represents the attainable IWUE if all irrigation water is transpired by the crop, hence, it can be used as a benchmark to diagnose on-farm efficiency. Following this approach, average on-farm IWUE of irrigated soybean in NE of $5.5 \mathrm{~kg} \mathrm{ha}^{-1} \mathrm{~mm}^{-1}$ was $32 \%$ below the attainable IWUE, which is very consistent with the analysis of water productivity in irrigated maize in NE reported by Grassini et al. (2011b). However, we suspect that attainable IWUE for soybean may be $>8 \mathrm{~kg} \mathrm{ha}^{-1} \mathrm{~mm}^{-1}$ because (i) in some region-years, on-farm IWUE approached or even exceeds the attainable IWUE (Figure 9b) and (ii) sowing dates in the study by Suyker and Verma (2009) were relatively late (May 20 and June 2), hence, it is likely that higher yields and thus higher IWUE may have been achieved if crops would have been sown earlier.

There was significant variation in IWUE among years as indicated by the high inter-annual CV (range: $15-31 \%$ across regions). Irrigation system type had the largest impact on IWUE. In region I, where it was possible to disaggregate the data by irrigation system, IWUE was $65 \%$ higher in pivot-irrigated than in surface-irrigated fields (7.6 versus $4.6 \mathrm{~kg} \mathrm{ha}^{-1} \mathrm{~mm}^{-1}$, respectively). Spatial and interannual variation in IWUE was not consistently associated with total rainfall, $\mathrm{ET}_{\mathrm{O}}$, crop water deficit, or average relative humidity during the July 1 -August 15 time period $(P>0.15)$. It was possible, however, to aggregate the five regions shown in Figure $9 \mathrm{~b}$ into three categories: low irrigation amount, high IWUE (regions I and II), low irrigation amount, low IWUE (regions III and V), and high irrigation amount, low IWUE (region VI). Underpinning factors for lowIWUE regions may be associated with excessive irrigation amount compared with crop water requirements that are, in turn, related to (i) difficulties to match irrigation timing with in-season rainfall events in the higher rainfall areas (regions III and V) and (ii) dealing with the need for more frequent irrigation events in fields that have sandy soils with low water holding capacity (region V) (Table 5). Year-toyear variation on IWUE across years, within the same region, may be related to the degree of synchronization between applied irrigation and rainfall events. For example, in years in which rainfall events randomly occurred shortly after irrigation was applied would lead to low IWUE. Also, in hot summers, producers must deal with restrictions on electricity supply (needed to power ground water pumps) for irrigation in rural areas, due to competition with electricity use for air conditioning in urban areas, which could lead to sub-optimal irrigation timing in some regions.

\section{5. $N$ supply in soybean production}

Components of $\mathrm{N}$ supply for irrigated soybean production measured in this study included inorganic soil $\mathrm{N}^{-\mathrm{NO}_{3}}{ }^{-}$, irrigation water $\mathrm{N}_{-} \mathrm{NO}_{3}{ }^{-}$, and $\mathrm{N}$ fertilizer, and the average supply was $94 \mathrm{~kg} \mathrm{~N} \mathrm{ha}^{-1}$ from these sources (Table 6). Of the total measured $\mathrm{N}$ supply, 55, 39 , and $6 \%$ were respectively attributable to soil $\mathrm{N}^{-\mathrm{NO}_{3}}{ }^{-}$at sowing, irrigation water $\mathrm{N}^{-\mathrm{NO}_{3}}{ }^{-}$, and $\mathrm{N}$ fertilizer, respectively. $\mathrm{N}$ fertilizer, typically applied as 'starter' on or shortly after soybean sowing, was reported in $<10 \%$ of the fields in all regions, except for northern regions V and VI (14 and $41 \%$ of the fields, respectively). Starter N application is more frequent in relatively cooler springs (which is the usual case in these two regions) and in sandy soil fields with low $\mathrm{N}$ mineralization capacity which induces producers to apply starter $\mathrm{N}$ to ensure a more vigorous seedling establishment and early vegetative growth. Average (2004-2011) mean temperature in regions V and VI in the April 15-May 15 interval was 11.4 and $11.2^{\circ} \mathrm{C}$, respectively, whereas it ranges from 12.5 to $13.7^{\circ} \mathrm{C}$ across the other four regions. Remarkably, soybean received, on average, about $40 \mathrm{~kg} \mathrm{~N}^{-1}$ via irrigation water application, mostly applied during the reproductive 
Table 6. Mean (2004-2011) soil ${\mathrm{N}-\mathrm{NO}_{3}}^{-}(0-0.9 \mathrm{~m}$ depth) just before or after soybean sowing date, $\mathrm{N}$ fertilizer application rate in soybean fields that did receive

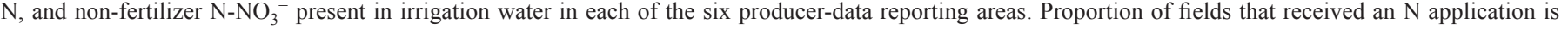
shown in parenthesis. Also shown in the total $\mathrm{N}$ supply (sum of soil $\mathrm{N}_{-} \mathrm{NO}_{3}{ }^{-}, \mathrm{N}$ fertilizer rate weighted by $\%$ of fields that received $\mathrm{N}$ application, and non-fertilizer $\mathrm{N}^{-\mathrm{NO}_{3}}{ }^{-}$in irrigation water) is also shown.

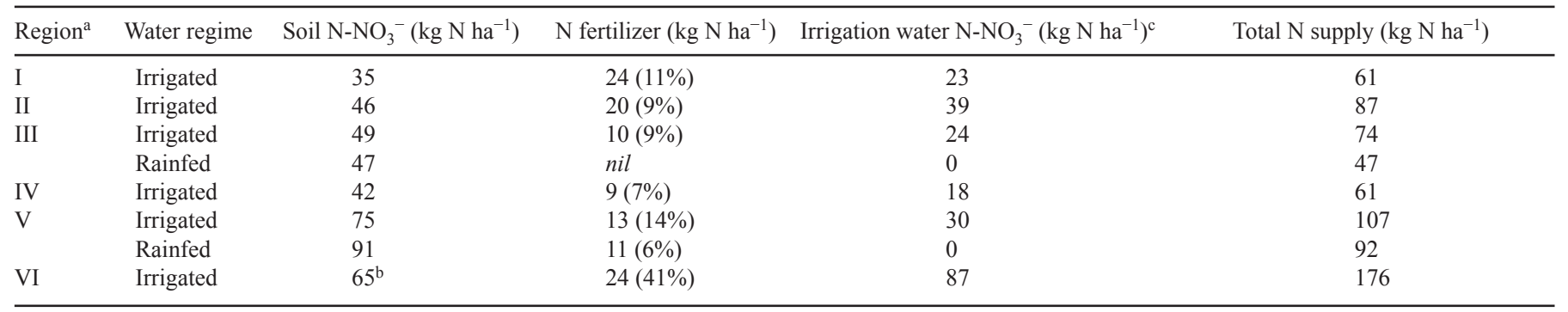

a. 2004 data were not available in region I and V.

b. Soil $\mathrm{N}_{-} \mathrm{NO}_{3}{ }^{-}$in region $\mathrm{VI}$ was reported at a $0-0.6 \mathrm{~m}$ depth.

c. Non-fertilizer $\mathrm{N}_{-} \mathrm{NO}_{3}{ }^{-}$in irrigation water was calculated based on producer-reported applied irrigation and $\mathrm{N}^{-\mathrm{NO}_{3}}{ }^{-}$concentration in irrigation water.

stages (Table 6). In high-yield soybean systems $\left(>4.5 \mathrm{Mg} \mathrm{ha}^{-1}\right)$, the extra $\mathrm{N}$ input through irrigation water during reproductive stages can help alleviate $\mathrm{N}$ limitation to crop growth due to declining biological N fixation and insufficient soil N (Salvagiotti et al., 2009). On the other hand, rainfed soybean fields rarely received $\mathrm{N}$ fertilizer inputs which, together with the lack of $\mathrm{N}$ input via irrigation water, helps explain the difference in yield between irrigated and rainfed yield that is unrelated per se with water supply (see Section 3.2).

Despite substantial $\mathrm{N}$ supply from soil $\mathrm{N}^{-\mathrm{NO}_{3}}{ }^{-}$at sowing, $\mathrm{N}^{-\mathrm{NO}_{3}}{ }^{-}$in applied irrigation and fertilizer as found in this study (average of $94 \mathrm{~kg} \mathrm{~N} \mathrm{ha}^{-1}$ ), symbiotic $\mathrm{N}_{2}$ fixation is likely a much larger source of $\mathrm{N}$ for the soybean crop. For example, based on average irrigated yield levels of 3.7 to $4.4 \mathrm{Mg} \mathrm{ha}^{-1}$ found in across regions in this study, total $\mathrm{N}$ uptake requirements would range from 300 to $360 \mathrm{~kg} \mathrm{~N} \mathrm{ha}^{-1}$ and the contribution from $\mathrm{N}_{2}$ fixation would be 50 $55 \%$ of total crop $\mathrm{N}$ uptake (Salvagiotti et al., 2008).

\section{Conclusions}

To our knowledge, this is the first study in reporting on-farm yield gaps, irrigation water use, and IWUE for high-yield irrigated soybean systems. Irrigated soybean yields are high and stable in NE, representing $84 \%$ of estimated attainable yield, when the latter is derived from highest-yielding fields. Irrigation attenuates spatial (i.e., regional) differentials in rainfall and in soil water holding capacity. The amount of irrigation applied each year depends on both rainfall and $\mathrm{ET}_{0}$. Remarkably, efficiency in use of rainfall and irrigation water to produce yield appeared to be almost identical. Spatial and annual variation in irrigated yields were not consistently explained by one or more of the ten examined meteorological factors. Instead, sowing date explained a large portion of the observed year-to-year variation in yield. In contrast, variation in rainfed yield was strongly related to rainfall during the reproductive growth phase. Another important finding was that field-to-field variation in yield and irrigation amount, even within relatively small and homogenous regions, was larger than year-to-year variation, reflecting the importance of producer management decisions, inherent soil-related constraints, and type of irrigation system. Future research will be oriented to understand causes of the observed field-to-field variation in yield and irrigation amount with the goal of identifying options to improve yield, water use efficiency, and profit.

Acknowledgments - We especially thank the 20 Nebraska Natural Resources Districts (NRD) that collaborated in this project by providing to us NRD-required producer-reported data. We also thank Dr. Lijun Zuo (Institute of Remote Sensing and Digital Earth, Chinese Academy of Sciences) for helping prepare Figure 1, Rebecca Davis (Risk Management Agency, RMA-USDA) for providing the sowing progress data, Federico Trindade (University of Nebraska-Lincoln) for assistance in the calculation of growing degree days, and Maribeth Milner (University of Nebraska-Lincoln) for helping to identify the mean sowing date in each region and year. This project was funded by the Nebraska Soybean Board.

\section{References}

Allen, R. G., Pereira, L. S., Raes, D., Smith, M., 1998. Crop Evapotranspiration: Guidelines for Computing Crop Water Requirements, FAO Irrigation and Drainage Paper 56. FAO, Rome, Italy.

Bastidas, A. M., Setiyono, T. D., Dobermann, A., Cassman, K. G., Elmore, R. W., Graef, G. L., Specht, J. E., 2008. Soybean sowing date: The vegetative, reproductive, and agronomic impacts. Crop Sci. 48, $727-740$.

Calviño, P. A., Andrade, F. H., Sadras, V. O., 2003a. Maize yield as affected by the interaction among rainfall, soil depth and crop management. Agron. J. 95, 275-281.

Calviño, P. A., Sadras, V. O., 1999. Interannual variation in soybean yield: interaction among rainfall, soil depth and crop management. Field Crops Res. 63, 237-246.

Calviño, P. A., Sadras, V. O., 2002. On-farm assessment of constraints to wheat yield in the south-eastern Pampas. Field Crops Res. 74, 1-11.

Calviño, P. A., Sadras, V. O., Andrade, F. H., 2003b. Development, growth and yield of late-sown soybean in the southern Pampas. Field Crops Res. 19, 265-275.

Calviño, P. A., Sadras, V. O., Andrade, F. H., 2003c. Quantification of environmental and management effects on the yield of late-sown soybean. Field Crops Res. 83, 67-77.

Cicchino, M., Rattalino Edreira, J. I., Uribelarrea, M., Otegui, M. E., 2010. Heat stress in field-grown maize: Response of physiological determinants of grain yield. Crop Sci. 50, 1438-1448.

De Bruin, J. L., Pedersen, P., 2008. Soybean seed yield response to planting date and seeding rate in the Upper Midwest. Agron. J. 100, 696-703.

Evans, L. T., 1993. Crop Evolution, Adaptation, and Yield. Cambridge University Press, Cambridge, UK. FAOSTAT Database-Agricultural Production (FAO) Online http://faostat.fao.org/ (accessed December 1, 2013).

Fermont, A. M., van Asten, P. J. A., Tittonell, P., van Wijk, M. T., Giller, K. E., 2009. Closing the cassava yield gap: An analysis from smallholder farms in East Africa. Field Crops Res. 112, 24-36. 
Fischer, R. A., 1985. Number of kernels in wheat crops and the influence of solar radiation and temperature. J. Agric. Sci., Camb. 105, $447-461$.

French, R. J., Schultz, J. E., 1984. Water use efficiency of wheat in a Mediterranean type environment. I. The relation between yield, water use and climate. Aust. J. Agric. Res. 35, 743-764.

Grassini, P., Hall, A. J., Mercau, J. L., 2009. Benchmarking sunflower water productivity in semiarid environments. Field Crops Res. 110, 251-262.

Grassini, P., Specht, J., Tollenaar, T., Ciampitti, I., Cassman, K. G., 2014. High-yield maize-soybean cropping systems in the U. S. Corn Belt. In: Sadras VO \& Calderini DF, eds., Crop Physiology-Applications for genetic improvement and agronomy (second ed.), Elsevier, Netherlands (in press).

Grassini, P., Thorburn, J., Burr, C., Cassman, K. G., 2011a. High-yield irrigated maize systems in the Western U. S. Corn-Belt. I. On-farm yield, yield-potential, and impact of agronomic practices. Field Crop Res. 120, 142-150.

Grassini, P., Yang, H., Irmak, S., Thorburn, J., Burr, C., Cassman, K. G., 2011b. High-yield irrigated maize systems in the Western U. S. CornBelt. II. Irrigation management and crop water productivity. Field Crop Res. 120, 133-141.

Howell, T. A., 2001. Enhancing water use efficiency in irrigated agriculture. Agron. J. 93, 281-289.

Irmak, S., Burgert, M. J., Yang, H., Cassman, K. G., Walters, D. T., Rathje, W. R., Payero, J. O., Grassini, P., Kuzila, M. S., Brunkhorst, K. J., Van De Walle, B., Rees, J. M., Kranz, W. L., Eisenhauer, D. E., Shapiro, C. A., Zoubek, G. L., Teichmeier, G. J., 2011. Large-scale implementation of soil moisture-based irrigation strategies for increasing maize water productivity. Trans. ASABE 55, 881-894.

Laborte, A. G., DeBie, C. A. J. M., Smaling, E. M. A., Moya, P. F., Boling, A. A., Van Ittersum, M. K., 2012. Rice yields and yield gaps in Southeast Asia: Past trends and future outlook. Eur. J. Agron. 36, 9-20.

Lobell, D. B., Cassman, K. G., Field, C. B., 2009. Crop yield gaps: Their importance, magnitudes, and causes. Ann. Rev. Environ. Resour. 34, 179-204.

Lobell, D. B., Ortiz-Monasterio, J. I., Addams, C. L., Asner, G. P., 2002. Soil, climate, and management impacts on regional wheat productivity in Mexico from remote sensing. Agric. For. Meteoro. 114, 31-43.

Mercau, J. L., Sadras, V. O., Satorre, E. H., Messina, C., Balbi, C., Uribelarrea, M., Hall, A. J., 2001. On-farm assessment of regional and seasonal variation in sunflower yield in Argentina. Agric. Syst. 67, 83-103.

Rondanini, D., Savin, R., Hall, A. J., 2003. Dynamics of fruit growth and oil quality of sunflower (Helianthus annuus L.) exposed to brief intervals of high temperature during grain filling. Field Crops Res. 83, 79-90.

Rowntree, S. C., Suhre, J. J., Wilson, E. W., Davis, V. M., Diers, B. W., Casteel, S. N., Esker, P. D., Specht, J. E., Conley, S. P., 2013. Genetic gain $\times$ management interactions in soybean: I. Planting date. Crop Sci. 53, 1128-1138.

Sadras, V., Roget, D., O’Leary, G. O., 2002. On-farm assessment of environmental and management constraints to wheat yield and efficiency in the use of rainfall in the Malle. Aust. J. Agric. Res. 53, 587-598.

Salvagiotti, F., Cassman, K. G., Specht, J. E., Walters, D. T., Weiss, A., Dobermann, A., 2008. Nitrogen uptake, fixation and response to fertilizer N in soybeans: A review. Field Crops Res. 108, 1-13.
Salvagiotti, F., Specht, J. E., Cassman, K. G., Walters, D. T., Weiss, A., Dobermann, A., 2009. Growth and nitrogen fixation in high-yielding soybean: Impact of nitrogen fertilization. Agron. J. 101, 958-970.

Scanlon, B. R., Faunt, C. C., Longuevergne, L., Reedy, R. C., Alley, W. M., McGuire, V. L., McMahon, P. B., 2012. Groundwater depletion and sustainability of irrigation in the U. S. high plains and central valley. Proc. Natl. Acad. Sci. 109, 9320-9325.

Setiyono, T. D., Weiss, A., Specht, J., Bastidas, A. M., Cassman, K. G., Dobermann, A., 2007. Understanding and modeling the effect of temperature and day length on soybean phenology under high-yield conditions. Field Crop Res. 100, 257-271.

Snyder, R. L., 1985. Hand calculating degree days. Agric. For. Meteoro. $35,353-358$.

Soil Survey Staff, USDA Natural Resources Conservation Service, 2013. U. S. General Soil Map (STATSGO2). Online http://soildatamart. nrcs.usda.gov (accessed December 1, 2013).

Specht, J. E., Chase, K., Macrander, M., Graef, G. L., Chung, J., Markwell, J. P., Germann, M., Orf, J. H., Lark, K. G., 2001. Soybean response to water: A QTL analysis of drought tolerance. Crop Sci. 41, 493-509.

Specht, J. E., Hume, D. J., Kumudini, S. V., 1999. Soybean yield potential-A genetic and physiological perspective. Crop Sci. 39, 1560-1570.

Suyker, A. E., Verma, S. B., 2009. Evapotranspiration of irrigated and rainfed maize-soybean cropping systems. Agric. For. Meteor. 149, 443-452.

Tittonell, P., Shepherd, K. D., Vanlauwe, B., Giller, K. E., 2008. Unravelling the effects of soil and crop management on maize productivity in small holder agricultural systems of western Kenya-An application of classification and regression tree analysis. Agric. Ecos. Env. 123, 137-150.

USDA-National Agricultural Statistics Service(NASS). Crops U. S. state and county databases, Washington, DC. Online http://www.nass.usda. gov/index.asp (accessed December 1, 2013).

USDA-National Agricultural Statistics Service (NASS), 2011. Nebraska Rank and Agribusiness Facts. Nebraska Energy Office, Lincoln, NE. Online http://www.neo.ne.gov/statshtml/73a.html (accessed December 1, 2013).

Van Ittersum, M. K., Cassman, K. G., Grassini, P., Wolf, J., Tittonell, P., Hochman, Z., 2013. Yield gap analysis with local to global relevance-A review. Field Crop Res. 143, 4-17.

Van Ittersum, M. K., Rabbinge, R., 1997. Concepts in production ecology for analysis and quantification of agricultural input-output combinations. Field Crops Res. 52, 197-208.

Villamil, M. B., Davis, V. M., Nafziger, E. D., 2012. Estimating factor contributions to soybean yield from farm field data. Agron. J. 104, 881-887.

Wairegi, L. W. I., vanAsten, P. J. A., Tenywa, M. M., Bekuna, M. A., 2010. Abiotic constraints override biotic constraints in East African highland banana systems. Field Crops Res. 117, 146-153.

Yonts, C. D., Eisenhauer, D. E., Varner, D. L., 2007. Managing furrow irrigation systems. Nebguide G1338, University of Nebraska-Lincoln. Online http://www.ianrpubs.unl.edu/epublic/live/g1338/build/g1338. pdf (accessed December 1, 2013).

Zhou, Y., Narumalani, S., Waltman, W. J., Waltman, S. W., Palecki, M. A., 2003. A GIS-based spatial pattern analysis model for eco-region mapping and characterization. Int. J. Geog. Inf. Sci. 17, 445-462. 